\title{
A Systematic Literature Review of the Solar Photovoltaic Value Chain for a Circular Economy
}

\author{
Maria A. Franco *(D) and Stefan N. Groesser (D) \\ Department of Industrial Engineering and Management Science, School of Engineering and Information \\ Technology, Bern University of Applied Sciences, 2501 Biel, Switzerland; stefan.groesser@bfh.ch \\ * Correspondence: maria.francomosquera@bfh.ch
}

check for updates

Citation: Franco, M.A.; Groesser, S.N. A Systematic Literature Review of the Solar Photovoltaic Value Chain for a Circular Economy. Sustainability 2021, 13, 9615. https://doi.org/ $10.3390 /$ su13179615

Academic Editor: Miguel Ángel Reyes Belmonte

Received: 28 June 2021

Accepted: 15 August 2021

Published: 26 August 2021

Publisher's Note: MDPI stays neutral with regard to jurisdictional claims in published maps and institutional affiliations.

Copyright: (c) 2021 by the authors. Licensee MDPI, Basel, Switzerland. This article is an open access article distributed under the terms and conditions of the Creative Commons Attribution (CC BY) license (https:/ / creativecommons.org/licenses/by/ $4.0 /)$.

\begin{abstract}
As the solar photovoltaic market booms, so will the volume of photovoltaic (PV) systems entering the waste stream. The same is forecast for lithium-ion batteries from electric vehicles, which at the end of their automotive life can be given a second life by serving as stationary energy storage units for renewable energy sources, including solar PV. The main objective of this paper is to systematically review the "state-of-the-art" research on the solar PV value chain (i.e., from product design to product end-of-life), including its main stages, processes, and stakeholder relationships, in order to identify areas along the value chain where circular strategies could be implemented, thereby advancing the transition of the PV industry towards circularity. To achieve this goal, we conducted a systematic literature review of 148 peer-reviewed articles, published in English between 2000 and 2020. Results show the PV value chain has been studied from a forward flow supply chain perspective and mostly from a technological point of view, with little regard for circular design, circular business models, and PV reuse. This article thus takes an integrated value chain perspective, introduces some of the barriers to circularity that industry players face, and argues that these barriers represent future opportunities for incumbent and new entrants to innovate within a circular PV industry.
\end{abstract}

Keywords: solar PV; EV batteries; circular economy; circular photovoltaic industry; PV reuse; PV recycling

\section{Introduction}

Solar photovoltaic (PV) energy, or the capture of solar radiation through photovoltaic panels to produce electricity, is considered one of the most promising markets in the portfolio of renewable energies, due to its potential to mitigate global warming and meet the $\mathrm{CO}_{2}$ reduction targets imposed by national governments and international agreements. The PV industry has grown nearly exponentially in recent years, as showcased by the increasing production volumes and the growing networks of solar installers and financing schemes worldwide. In 2018, global cumulative installed PV capacity reached almost $480 \mathrm{GW}$, representing about $2 \%$ of the world's electricity output [1]. By 2030, it is estimated that global capacity could reach 2840 GW, while by 2050, it may reach $8500 \mathrm{GW}$ [2]. Other things being equal, and assuming the average lifetime of a PV panel is 25 years, one can expect the accelerated growth in PV deployment to be translated into an exponential increase in end-of-life (EOL) PV waste in the years to come. PV panel waste projections, in fact, show that between 1.7-8 and 60-78 million tons of waste will be lying in landfills by 2030 and 2050, respectively [3]. Up until now, PV systems have operated under a linear "take-make-use-dispose" model, whereby natural resources are extracted, panels are manufactured, commercialized, used, and then mostly disposed of in landfills, where soil and groundwater contamination can occur [4]. For the PV industry to reduce and eliminate waste altogether, a circular, lifecycle perspective needs to be incorporated. Such a perspective will demand changes throughout the PV value chain, from product design to product end-of-life and the collaboration of a wide range of stakeholders, namely businesses, governments, customers, and academia. 
Aimed at supporting an informed transition of the PV industry towards a circular economy (CE), this article proposes a systematic literature review (SLR) to understand the current configuration and functioning of the PV value chain, including the issue of reusing electric vehicle (EV) batteries for small-scale solar energy storage, in order to identify potential areas where circular strategies could be implemented. We deem the study of the PV value chain necessary for various reasons. First, current literature has seldom looked at the PV value chain as one holistic entity and at the stakeholders that play a role in its functioning $[5,6]$. Research focusing on photovoltaic systems has been studied mostly from a forward flow supply chain perspective (i.e., polysilicon production, cell and module manufacturing, PV system installation and recycling), while paying little, although increasingly more, attention to other equally important value chain stages such as R\&D for circular product design and circular business models, as well as PV refurbishing, reuse, and recycle. Second, if one is to understand the dynamics guiding the evolution of PV systems, and to expect large-scale PV deployment in the future, a value chain view of the industry is necessary. Failing to account for the different networks that are part of the PV ecosystem can prevent policymakers and new market entrants from recognizing, for instance, that changes in public policy, technology, market conditions or consumer behavior will affect the relative attractiveness and diffusion trajectories of the different PV technologies [7] and the extent to which different circular paths for PV can be realized.

Third, to deal with PV waste effectively, innovation from product design to product recovery is essential. It has been argued that innovation in the renewable energy sector is increasingly distributed and interdependent, as it requires cooperation from incumbent and start-up firms, governments, research institutions, service providers, and so on [8]. Because these actors often display their own value chain structures and interactions, knowledge about these structures can provide opportunities for joint value discovery and creation $[9,10]$. Fourth, the projected scarcity of critical materials, such as tellurium, gallium, indium, and selenium in thin-film solar cell technologies, or lithium, cobalt, nickel, and natural graphite in EV batteries, also calls for a value chain view. By identifying risks and volatilities along the PV and EV battery value chains, stakeholders can prepare for imminent supply disruptions and ensure the sustainability and resilience of their supply chains [11,12].

Finally, if the goal is to aim for high-value PV reuse and recycling, circular product design and business model strategies must be incorporated in industry practices. For instance, current PV panel designs do not facilitate the effective separation of materials upon disposal, which provides incentives for low-value recycling and landfilling. Similarly, current product-focused business models rarely allow for product maintenance, refurbishing, take-back, or recycling. The development of a circular mindset among the actors of the PV value chain, not only among the actors within the boundaries of the firm, is therefore critical to secure the availability of secondary raw materials and to prevent, delay, or mitigate environmental damage.

Considering the ever-increasing attention given to PV energy and PV waste, this study's main goals are: (i) to understand how the PV value chain operates, including its main stages and processes, stakeholders, and the interactions among them; and (ii) to investigate which factors inhibit the incorporation of circular economy principles in the existing PV value chain. The remainder of this article is organized as follows: Section 2 briefly introduces the value chain framework, Section 3 provides a detailed view of the methodological framework used to plan and execute this systematic literature review, Section 4 presents a descriptive analysis of the reviewed article database, while Section 5 describes the main stages of the value chain for PV systems. Finally, Section 6 presents the conclusions of this study, and Section 7 poses some questions for future analysis.

\section{Analytical Framework and Related Literature}

Understanding how PV systems are developed, manufactured, sold, and managed throughout their lifetimes demands a value chain view. The concept of a value chain 
was coined by Michael Porter as a means of breaking down the activities of the firm into strategically relevant stages, processes, and relationships related to a product or service during the process of delivering "value" for a customer. Such activities involve product manufacturing, product delivery to consumers, and product disposal and/or reprocessing after use [13]. Although initially developed to help understand the value creation process at the firm level, the value chain concept is now also used as a tool for understanding value creation in industries and countries [14,15]. At the industry level, a value chain analysis provides a comprehensive view of an industry, thereby supporting strategic and technology planning for incumbents and new entrants, as well as policy making at a higher level [16].

The accelerated transition to a CE requires research on all relevant aspects of the value chain. In the literature, terms such as "circular value chain," "circular supply chain," "supply chain management in a circular economy," or "closed-loop supply chain" are sometimes used interchangeably. Different from the traditional linear value chain explained above, we define the value chain concept in this article as the myriad of activities involved both in the supply and the take-back chain of the PV industry. Our base definition therefore covers "all stages of the life cycle from idea/concept, raw material sourcing, production, distribution, and end customer use to the point where the product returns to a biological or technical cycle, thus closing the loop" [17]. A value chain perspective has therefore been chosen as means to identify hotspots for value creation at different stages of the PV lifecycle.

Despite the holistic view proposed in this article, most of the published systematic literature reviews linked to solar PV have showed a technical focus, covering topics such as: advances in solar cell research and testing [18-21], energy losses and degradation of PV modules [22-24], forecasting of solar photovoltaic radiation and electricity generation [25,26], digital technologies for PV monitoring [27], and leaching of metals from EOL PV waste $[28,29]$. Other review articles have been more market-oriented, highlighting the need for government interventions in supporting PV diffusion [30]; the factors influencing residential households' adoption of PV systems [31,32]; and descriptions of the current PV market, its associated costs, and available technologies [33]. Finally, a growing stream of literature focusing on the management of EOL PV modules has also emerged. For instance, [34] suggests that monitoring and reporting systems at the national and regional level can support the identification and management of current and future streams of PV waste. The authors also stress the need for reverse logistics between geographically close nodes and recycling centers. Furthermore, while analyzing the drivers, barriers, and enablers for the EOL management of PV and battery energy storage systems, [35] suggests that besides technology-related research, socio-economic research is also necessary to boost successful EOL implementation. Different from other review publications, the contribution of this article lies not only in showcasing the current barriers that impede PV and LIB reuse and recycling, and the overall achievement of industry circularity, but also in unveiling untapped opportunities for different stakeholders along the PV value chain.

\section{Methodology}

To investigate the research questions introduced in Section 1, we conducted a systematic literature review (SLR) by following the methodological framework proposed by Denyer and Tranfield [36] and Tranfield, Denyer and Smart [37]. A systematic literature review is a self-contained research project that uses existing studies to provide answers to research questions, which are usually derived from policy or practice. A systematic review differs from a traditional, more general, literature review in that it proposes a replicable, scientific, and transparent process, thereby creating a foundation for advancing knowledge in a particular field and facilitating theory development [38,39]. A summary of the employed methodology is displayed in Table 1. 
Table 1. Summary of the methodology.

\begin{tabular}{|c|c|c|c|}
\hline SLR Phase & Steps & Description & Article Section \\
\hline $\begin{array}{l}\text { Phase } 1 \\
\text { Formulate the } \\
\text { research question }\end{array}$ & $\mathrm{N} / \mathrm{A}$ & $\begin{array}{l}\text { - How does the current PV } \\
\text { value chain operate? } \\
\text { Which factors inhibit the } \\
\text { incorporation of CE principles } \\
\text { in the current value chain? }\end{array}$ & Section 1 \\
\hline \multicolumn{4}{|c|}{ Preliminary literature scan } \\
\hline \multirow{3}{*}{$\begin{array}{l}\text { Phase } 2 \\
\text { Locate studies }\end{array}$} & $\begin{array}{l}\text { Determine search methods } \\
\text { and engines }\end{array}$ & - Web of Science and Scopus & \multirow{3}{*}{ Section 3.2} \\
\hline & - $\quad$ Select types of data sources & $\begin{array}{l}\text { Journal articles and conference } \\
\text { papers published in English }\end{array}$ & \\
\hline & - $\quad$ Determine timeframe & - $\quad 2000-2020$ & \\
\hline \multirow[b]{2}{*}{$\begin{array}{l}\text { Phase } 3 \\
\text { Select and evaluate studies }\end{array}$} & - $\quad$ Define search strings & - $\quad$ See Table 2 & \multirow[b]{2}{*}{ Section 3.2} \\
\hline & - Define criteria for exclusion & $\begin{array}{l}\text { Articles that mixed PV with } \\
\text { other renewable energy } \\
\text { sources; were too technical; } \\
\text { discussed other types of solar } \\
\text { energy different from PV; and } \\
\text { discussed small-scale PV } \\
\text { applications }\end{array}$ & \\
\hline \multirow{2}{*}{$\begin{array}{l}\text { Phase } 4 \\
\text { Analyze and synthesize }\end{array}$} & - $\quad$ Define review protocol & - $\quad$ Excel & \multirow{2}{*}{$\begin{array}{l}\text { Supplementary file } \\
\text { Supplementary file }\end{array}$} \\
\hline & - $\quad$ Code and extract data & - $\quad$ Atlas.ti & \\
\hline \multirow{2}{*}{$\begin{array}{l}\text { Phase } 5 \\
\text { Report the findings }\end{array}$} & $\mathrm{N} / \mathrm{A}$ & $\begin{array}{l}\text { Descriptive analysis of the } \\
\text { article database }\end{array}$ & \multirow{2}{*}{$\begin{array}{l}\text { Section } 4 \\
\text { Section } 5\end{array}$} \\
\hline & & $\begin{array}{l}\text { - Value chain description for } \\
\text { PV systems }\end{array}$ & \\
\hline
\end{tabular}

\subsection{Phase 1: Planning the Review}

As a first step, and to ensure the validity, reliability, and replicability of the results, we developed a draft protocol for carrying out the literature review process. After agreeing on a structured process flow for the review, we decided to embark on an informal preliminary literature scan to better outline the scope of our research. The preliminary scan was instrumental in: (i) confirming that there was indeed a gap in the literature, (ii) delineating the thematic focus for the review as well as the exclusion criteria for the selection of articles, and (iii) defining the time frame and the set of keywords to be employed in the systematic search.

\subsection{Phases 2 and 3: Location, Selection, and Evaluation of Studies}

\subsubsection{Location}

The literature search was undertaken using two of the largest abstract and citation databases of peer-reviewed literature, namely Web of Science and Scopus. A search in both databases ensured that the review results considered all the available evidence and were based on quality contributions [36]. To identify the most reliable types of publications, we adhered to the "fit-for-purpose" rationale, which suggests that rather than a hierarchy of 
evidence (i.e., ranking of the publication outlet), the criteria for the selection of articles must rely on the purpose and context of the research. Hence, we delimited our search to peerreviewed articles in English, published in academic journals; proceedings of international conferences; and book chapters. The inclusion of conference papers ensured that the results covered the most recently available knowledge, especially concerning the use of EV batteries for the stationary storage of PV energy. Industry reports and other grey literature were intentionally excluded due to the challenges of collecting them systematically.

We set the keyword search's timeframe from 2000 to 2020 because solar energy markets only regained momentum from the early 2000s [40]. Similarly, sales of EVs also started to take off since the beginning of the 21st century. Finally, we extended our search to the year 2020 after realizing that a significant number of scholarly articles had been published just recently. The choice of time frame was confirmed during the preliminary literature scan, when the search results returned almost no publications before the year 2000 and a rising number of published articles within the past three years.

\subsubsection{Selection and Evaluation}

After conducting the actual search using the set of keywords displayed in Table 2, all information from the resulting articles (e.g., title, abstract, keywords, publication year, and publication outlet) was exported to two Excel spreadsheets (i.e., one for Web of Science results and another for Scopus results). The two databases were then merged into one $(n=371)$ and the combined results analyzed to identify duplicate entries $(n=27)$. Once identified, duplicates were tagged and removed from the merged database.

Table 2. Database search summary.

\begin{tabular}{|c|c|c|c|c|}
\hline Keywords & Database & Type of Document & Language & Quantity \\
\hline $\begin{array}{l}\text { TITLE-ABS-KEY (("supply chain*" OR "value } \\
\text { chain*") AND ("photovoltaic" OR "solar" OR "pv") } \\
\text { AND NOT ("wind*" OR "biomass" OR "biofuel" OR } \\
\text { "biogas" OR "hydro")) AND PUBYEAR > } 1999 \text { AND } \\
\text { LANGUAGE ("English") }\end{array}$ & Scopus & $\begin{array}{l}\text { Journal articles and } \\
\text { conference papers }\end{array}$ & English & 179 \\
\hline $\begin{array}{c}\text { (TS = ((“supply chain*” OR “value chain*”) AND } \\
\text { (photovoltaic* OR solar OR pv) NOT (wind* OR } \\
\text { biomass OR biofuel OR biogas OR hydro*))) AND } \\
\text { LANGUAGE: (English) AND DOCUMENT TYPES: } \\
\text { (Article) Timespan: 2000-2018. Indexes: } \\
\text { SCI-EXPANDED, SSCI, A\&HCI, CPCI-S, CPCI-SSH, } \\
\text { BKCI-S, BKCI-SSH, ESCI, CCR-EXPANDED, IC. }\end{array}$ & Web of Science & $\begin{array}{l}\text { Journal articles and } \\
\text { conference papers }\end{array}$ & English & 192 \\
\hline
\end{tabular}

To determine whether an article met the inclusion criteria, we read the article's title and abstract, and, when necessary, scanned the article's complete content. This filtering process resulted in the exclusion of 215 articles, with a final number of 129 articles being considered for further analysis. Articles were removed from the merged database for various reasons, including: (i) their content did not match the topic of this study; (ii) access was restricted; (iii) they were deemed to be too technical or not fitting the scope of this review (i.e., a great number of publications addressed PV panel manufacturing and deployment exclusively from an engineering, materials science, chemical or electrical perspective or discussed only one stage of the PV value chain); (iv) they referred to alternative types of solar energy, such as solar thermal or concentrating solar power, or discussed solar PV only marginally (i.e., photovoltaic energy was mentioned along with other renewable energy sources such as hydropower, wind power, biomass, biogas, and biofuel); and (v) they referred to off-grid, small-scale PV applications, such as water heating, lightening or mobile charging, primarily in remote areas in Africa, or to related, yet different, value chains, such as refrigeration chains for food fueled by PV energy. Finally, the articles' list of cited references served as a secondary and additional source of analysis. Cross-referencing resulted in 19 articles being 
added to the primary database, resulting in a total of 148 articles being analyzed for the present review (see Figure 1).

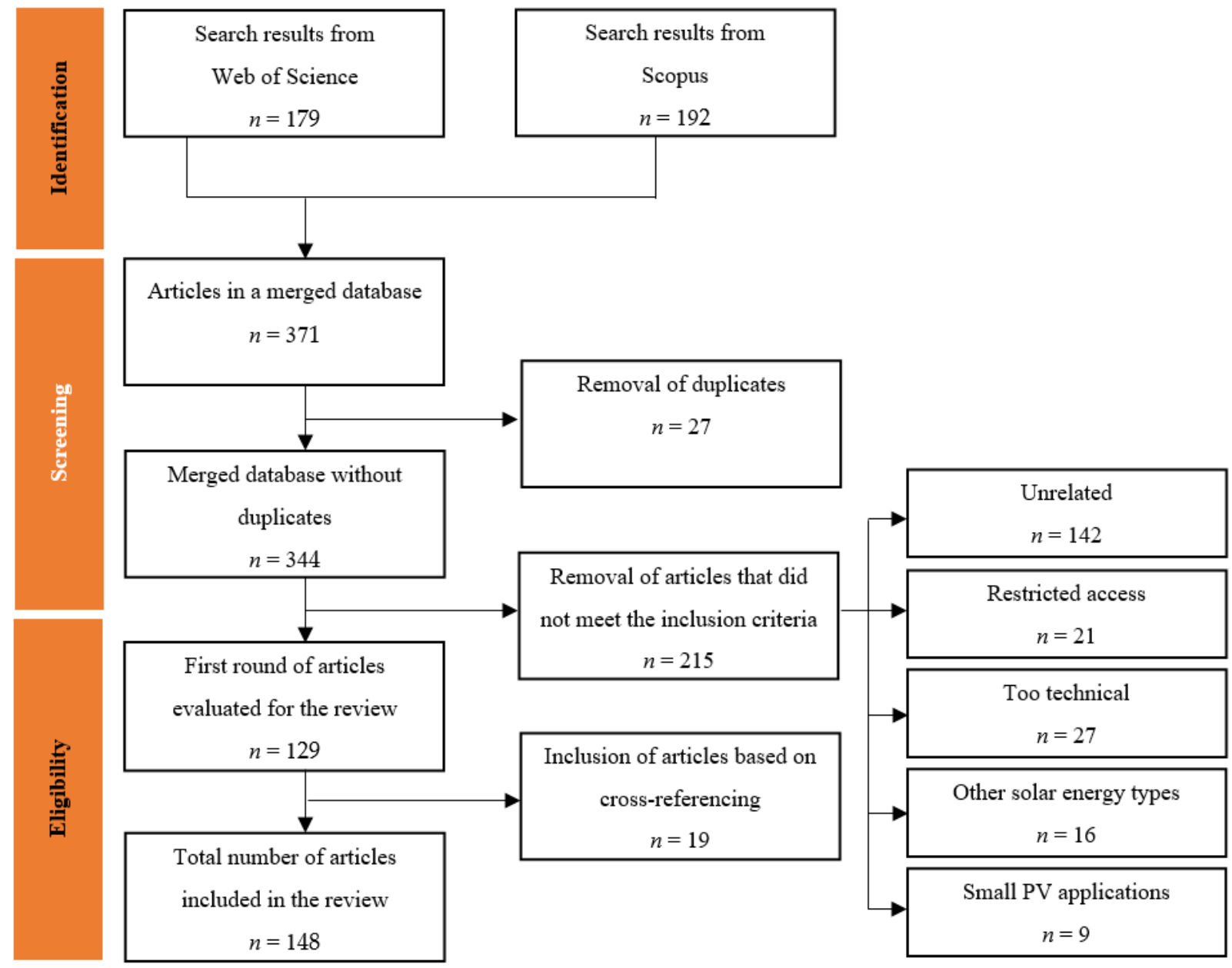

Figure 1. Flow diagram of the systematic review.

\subsection{Phase 4: Data Analysis and Coding Scheme}

In this final stage, we imported all the articles that met the inclusion criteria $(n=148)$ to the coding software Atlas.ti and read them all in detail to perform an open coding content analysis [41]. Using this technique, we coded the article's content inductively (i.e., open coding) and then structured the incoming data according to its relationship to the PV and EV battery value chains (i.e., axial coding). The established coding system included such labels as: UPSTREAM PV cell raw material, UPSTREAM PV cell manufacturing, DOWNSTREAM PV module recycling, and STAKEHOLDER equipment manufacturers. Throughout the coding process, we also kept a diary to track our thought process and to structure our analysis and findings. At the end of the coding stage, we reviewed each code and merged or deleted some of them for clarity. This process resulted in 214 codes that served as the basis for the content in this article.

\section{Analysis and Results: Descriptive Analysis}

\subsection{Number and Sources of Publications}

The trend indicates a growing interest within the academic community in solar photovoltaic-related research, especially since 2013 . Around $88 \%$ of the articles $(n=135)$ written between 2000 and 2020 have been published since 2013 (see Figure 2). The greatest number of publications occurred in $2018(n=34)$, exhibiting approximately a $140 \%$ increase since 2017. Overall, between 2013 and 2017, publications increased by an average of 14\% 
per year. Before 2013, it seems academic research was undergoing an incubation period, especially in relation to the analysis of value chain actors and dynamics.

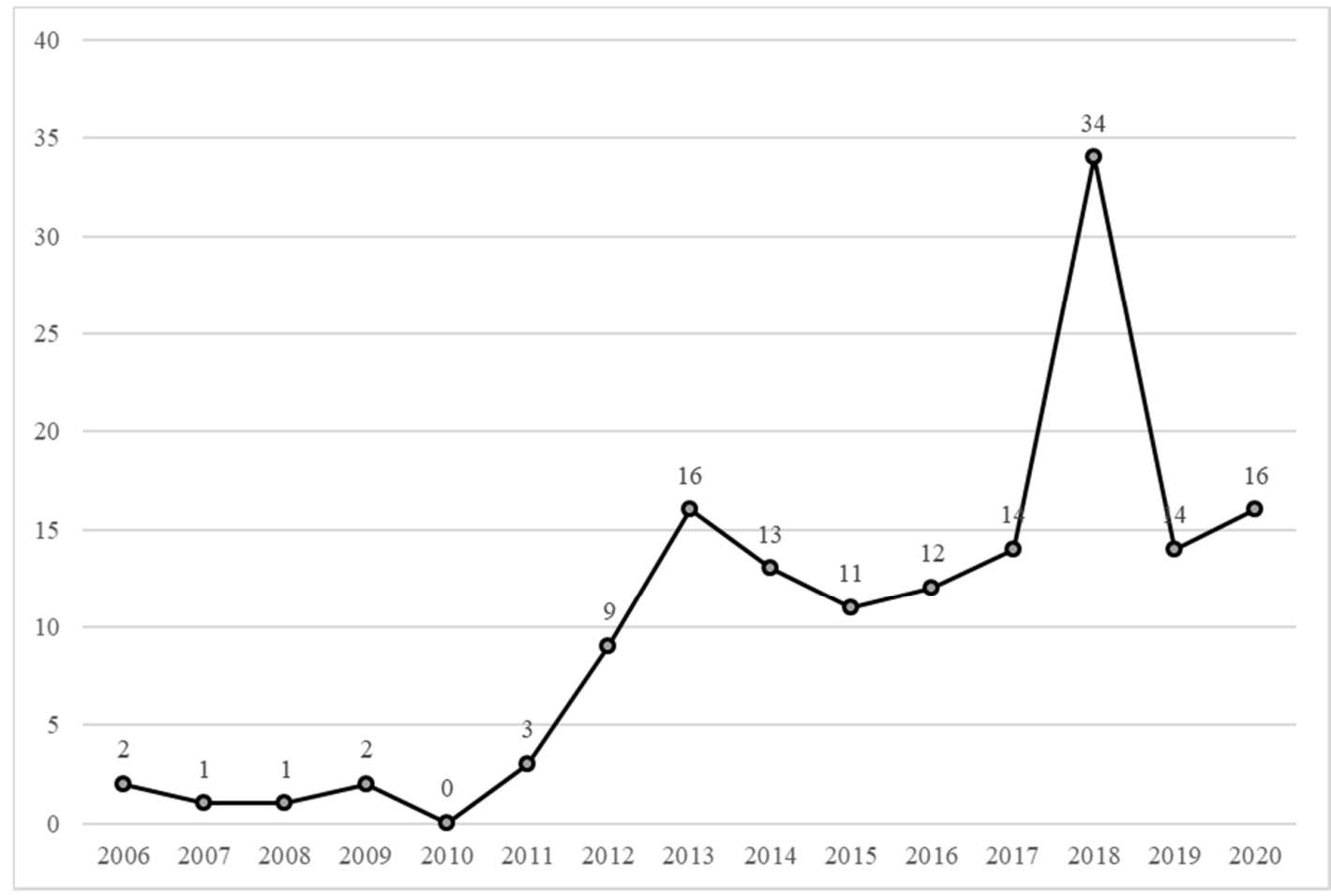

Figure 2. Distribution of reviewed publications over time $(n=148)$.

Figure 3 indicates that journal publications constituted the major avenue for disseminating research results. The academic journals with the highest number of publications were the Journal of Cleaner Production $(n=15)$, Energy Policy $(n=9)$, Renewable and Sustainable Energy Reviews $(n=8)$, Renewable Energy $(n=8)$, Sustainability $(n=6)$, and Applied Energy with 5 publications (see Tables 3 and 4). The six most prolific journals accounted for $35 \%$ of the analyzed records. Finally, results show that the topic of the PV value chain is suitable for publishing in a range of specialized journals $(n=68)$ that focus mainly on sustainability, the environment, and energy issues.

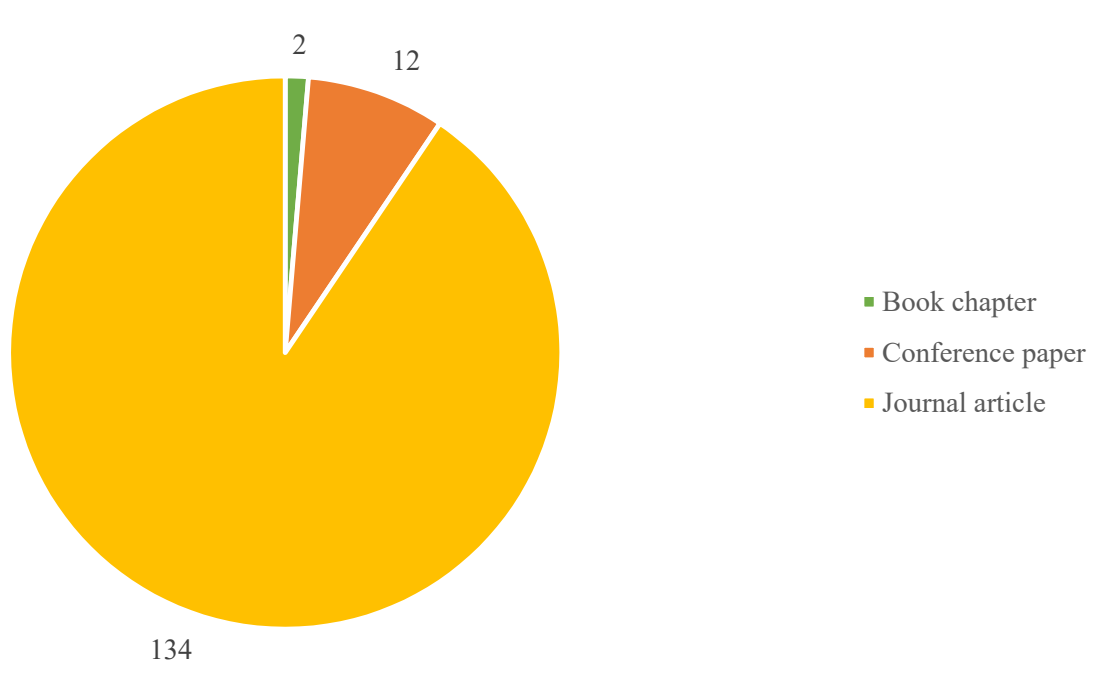

Figure 3. Proportion of journal, conference and book chapter publications $(n=148)$. 
Table 3. Number of publications per journal.

\begin{tabular}{|c|c|}
\hline Journal & Articles \\
\hline Journal of Cleaner Production & 15 \\
\hline Energy Policy & 9 \\
\hline Renewable and Sustainable Energy Reviews & 8 \\
\hline Renewable Energy & 8 \\
\hline Sustainability & 6 \\
\hline Applied Energy & 5 \\
\hline Clean Technologies and Environmental Policy & 3 \\
\hline Solar Energy Materials and Solar Cells & 3 \\
\hline Journal of Energy Storage & 3 \\
\hline Progress in Photovoltaics & 3 \\
\hline Energy Research and Social Science & 3 \\
\hline Energies & 3 \\
\hline Renewable Energy Focus & 2 \\
\hline International Journal of Photoenergy & 2 \\
\hline Ecological Indicators & 2 \\
\hline Energy for Sustainable Development & 1 \\
\hline Energy and Buildings & 2 \\
\hline Energy Conversion and Management & 2 \\
\hline Industrial and Corporate Change & 2 \\
\hline Environmental Innovation and Societal Transitions & 2 \\
\hline IEEE Journal of Photovoltaics & 2 \\
\hline Research Policy & 2 \\
\hline Journal of Energy in Southern Africa & 1 \\
\hline Waste Management & 1 \\
\hline Energy Sources Part B-Economics Planning and Policy & 1 \\
\hline International Journal of Production Economics & 1 \\
\hline Journal of Industrial Engineering and Management & 1 \\
\hline International Journal of Sustainable Energy & 1 \\
\hline International Journal of Low-Carbon Technologies & 1 \\
\hline International Journal of Technology Management and Sustainable Development & 1 \\
\hline International Journal of Construction Management & 1 \\
\hline International Studies Quarterly & 1 \\
\hline SAE International Journal of Manufacturing & 1 \\
\hline Energy Sources, Part A: Recovery, Utilization and Environmental Effects & 1 \\
\hline Journal of Power Sources & 1 \\
\hline Journal of East Asian Studies & 1 \\
\hline Solar Energy & 1 \\
\hline Computers \& Chemical Engineering & 1 \\
\hline International Journal of Environmental Research and Public Health & 1 \\
\hline Energy & 1 \\
\hline Electricity Journal & 1 \\
\hline Energy Strategy Reviews & 1 \\
\hline Technovation & 1 \\
\hline Joule & 1 \\
\hline Engineering & 1 \\
\hline IISE Transactions & 1 \\
\hline Batteries & 1 \\
\hline Energy Reports & 1 \\
\hline Sustainable Materials and Technologies & 1 \\
\hline Annals of The American Association of Geographers & 1 \\
\hline Energy Sources & 1 \\
\hline Environmental Research Letters & 1 \\
\hline European Planning Studies & 1 \\
\hline Energy and Environmental Science & 1 \\
\hline Flexible Services and Manufacturing Journal & 1 \\
\hline IEEE Transactions on Engineering Management & 1 \\
\hline Resources Conservation and Recycling & 1 \\
\hline Resources Policy & 1 \\
\hline
\end{tabular}


Table 3. Cont.

\begin{tabular}{cc}
\hline Journal & Articles \\
\hline Journal of Industrial Ecology & 1 \\
Business and Politics & 1 \\
Metallurgical Research \& Technology & 1 \\
International Journal of Sustainable Engineering & 1 \\
Ore Geology Reviews & 1 \\
Journal of Renewable and Sustainable Energy & 1 \\
Perspectives on Global Development and Technology & 1 \\
Physica Status Solidi A-Applications and Materials Science & 1 \\
African Journal of Business Management & 1 \\
Production and Operations Management & 1 \\
\hline
\end{tabular}

Table 4. Number of publications per conference.

\begin{tabular}{cc}
\hline Conference & Articles \\
\hline ASES National Solar Conference & 3 \\
PICMET Portland International Center for Management of Engineering & 2 \\
and Technology & 2 \\
IEEE India Conference & 1 \\
Global Conference on Sustainable Manufacturing & 1 \\
Energy Technology & 1 \\
ICDRET International Conference on The Developments in Renewable & 1 \\
International Conference on Service Systems and Service Management & 1 \\
IFIP Advances in Information and Communication Technology & 1 \\
Energy Procedia & 1 \\
\hline IEEE International Energy Conference & 1
\end{tabular}

\subsection{Methodological Trends}

Upon examination of the article database, we observed four approaches to research, namely: (i) literature review (i.e., a study that collects, reviews, and analyzes previously published research); (ii) modelling and simulation (i.e., a study that uses mathematical functions for decision-making); (iii) case study (i.e., a study that uses qualitative data to build a case exploring a problem); and (iv) theoretical and conceptual (i.e., a study that proposes a theory or a conceptual framework) [42] (see Figure 4).

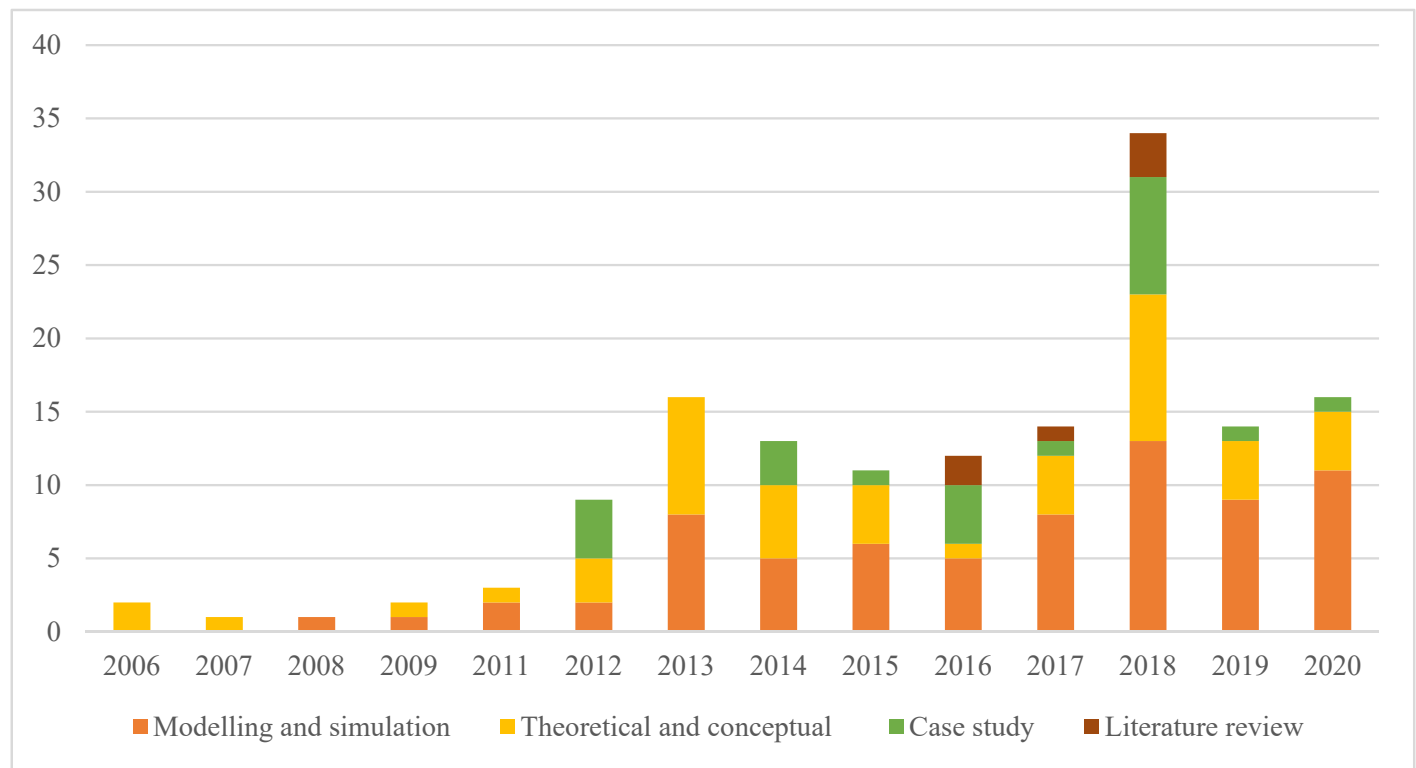

Figure 4. Temporal distribution of research methodologies. 
Modelling and simulation was by far the preferred methodology among researchers in the database (48\%). Some of the most popular modelling techniques included optimization, life cycle assessment, financial modelling, and techno-economic modelling. These methods were used to study a broad range of problems, such as environmental sustainability, competing supply chains, R\&D cooperation among actors in the value chain, and growth evolution of the PV industry in a specific location or for specific firms. Theoretical and conceptual papers ranked second in the list of the most preferred methods $(32 \%)$, followed by case studies $(16 \%)$ and literature reviews $(4 \%)$. As expected, the share of case study and literature review articles has been increasing only lately, following the recent boom in PV installations and scholarly publications on the topic.

\subsection{Geographical Trends}

European countries have been at the forefront of academic publishing in relation to solar PV systems (see Figure 5). Out of all the reviewed articles, 39\% had first authors who work at a European institution, with Germany, the United Kingdom, and Italy being the most active players. Asia and North America are also strong centers of publication, with $35 \%$ and $18 \%$ of the publications originating in these regions, respectively. China, which captures $55 \%$ of the articles in Asia, has had a much-publicized increase in its share of scientific output after becoming the largest producer of solar cells in 2007 and the largest producer of solar panels in 2008 [43]. Furthermore, developing countries present a marked contrast to the European and Chinese cases. While governmental sponsorship has been pivotal in fostering the establishment of a solar PV industry in Europe and China, policies for PV deployment in developing countries have been much less robust or even nonexistent, with data and academic research output being scant. For a summary of research subjects, methodologies employed, and author geography see Table 5 .

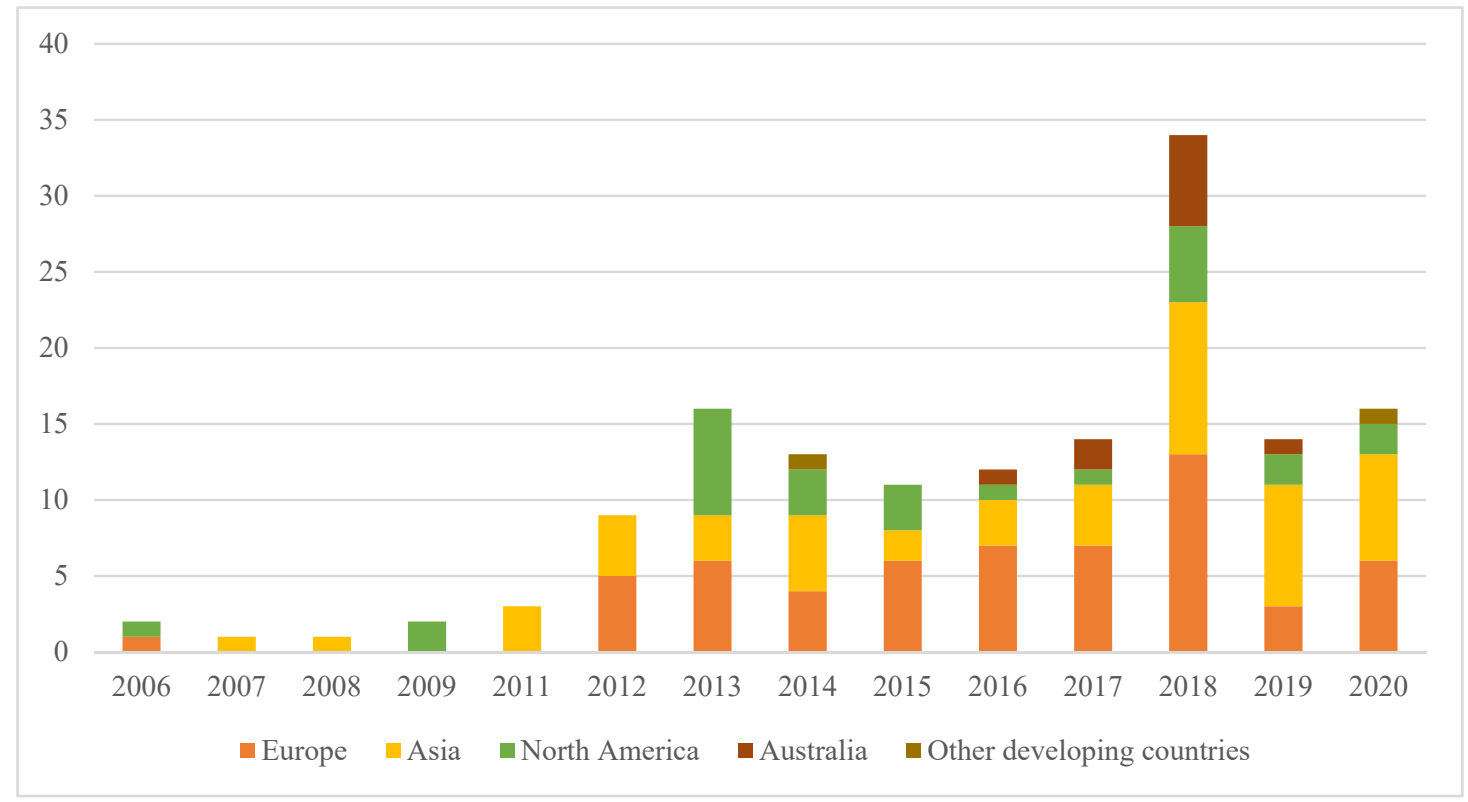

Figure 5. Temporal distribution of the geographical location of the first author.

Table 5. Distribution of published articles.

\begin{tabular}{lcc}
\hline \multicolumn{1}{c}{ Category } & No. of Articles & \% \\
\hline Research subject & 148 & $100 \%$ \\
PV panels & 127 & $86 \%$ \\
EV batteries & 14 & $9 \%$ \\
Both & 7 & $5 \%$ \\
\hline
\end{tabular}


Table 5. Cont.

\begin{tabular}{|c|c|c|}
\hline Category & No. of Articles & $\%$ \\
\hline \multicolumn{3}{|l|}{ Research methodology } \\
\hline Modelling and simulation & 71 & $48 \%$ \\
\hline Theoretical and conceptual & 48 & $32 \%$ \\
\hline Case study & 23 & $16 \%$ \\
\hline Literature review & 6 & $4 \%$ \\
\hline \multicolumn{3}{|l|}{ Geographical context } \\
\hline Europe & 58 & $39 \%$ \\
\hline Germany & 14 & \\
\hline UK & 10 & \\
\hline Italy & 9 & \\
\hline Norway & 5 & \\
\hline Spain & 4 & \\
\hline Switzerland & 4 & \\
\hline Netherlands & 4 & \\
\hline Denmark & 1 & \\
\hline Sweden & 2 & \\
\hline Czech Republic & 1 & \\
\hline Greece & 1 & \\
\hline Poland & 1 & \\
\hline Hungary & 1 & \\
\hline France & 1 & \\
\hline Asia & 51 & $35 \%$ \\
\hline China & 28 & \\
\hline Iran & 6 & \\
\hline Taiwan & 5 & \\
\hline Korea & 4 & \\
\hline Japan & 3 & \\
\hline India & 2 & \\
\hline Singapore & 2 & \\
\hline Bangladesh & 1 & \\
\hline North America & 27 & $18 \%$ \\
\hline USA & 25 & \\
\hline Canada & 1 & \\
\hline Mexico & 1 & \\
\hline Australia & 10 & $7 \%$ \\
\hline Other developing countries & 2 & $1 \%$ \\
\hline
\end{tabular}

\section{Analysis and Results: Discussion}

The solar PV value chain can be regarded as complex, not only technologically, but also because of the various supply chains, stakeholders, installation sizes, business models, and customer segments that it encompasses. Despite its inherent complexity, there is no comprehensive study that describes the interdependencies between the different value networks that play a role in the PV value chain [6]. Before presenting a detailed description of each stage of the PV value chain, however, Table 6 presents a classification of each reviewed publication according to the main themes that were identified in this SLR. 
Table 6. Publications per thematic group.

\begin{tabular}{|c|c|c|c|c|}
\hline $\begin{array}{l}\text { Stage of the PV } \\
\text { Value Chain }\end{array}$ & Category & Description & $\%$ & Reference \\
\hline \multirow{5}{*}{ Upstream } & Raw material & $\begin{array}{c}\text { Issues related to the raw materials used } \\
\text { in the manufacturing of silicon and } \\
\text { thin-film PV cells }\end{array}$ & $6 \%$ & {$[11,12,44-50]$} \\
\hline & Technologies & $\begin{array}{l}\text { Engineering processes in wafer, cell, and } \\
\text { module manufacturing }\end{array}$ & $5 \%$ & {$[51-57]$} \\
\hline & $\begin{array}{l}\text { Supply chain } \\
\text { collaboration }\end{array}$ & $\begin{array}{l}\text { Collaboration among supply chain } \\
\text { partners for innovation in PV } \\
\text { manufacturing or service provision }\end{array}$ & $7 \%$ & {$[7-9] *,[58-64]$} \\
\hline & Human resources & $\begin{array}{l}\text { Job markets and job creation in the } \\
\text { PV industry }\end{array}$ & $1 \%$ & {$[65,66]$} \\
\hline & PV system installation & $\begin{array}{l}\text { Issues related to BOS components and } \\
\text { the installation of PV systems }\end{array}$ & $1 \%$ & {$[67,68]$} \\
\hline \multirow{4}{*}{ Midstream } & Business models & $\begin{array}{l}\text { Business models used in the } \\
\text { PV industry }\end{array}$ & $2 \%$ & {$[69-71] *$} \\
\hline & $\begin{array}{l}\text { PV energy diffusion } \\
\text { and industry evolution }\end{array}$ & $\begin{array}{l}\text { Enablers and barriers for the diffusion } \\
\text { of PV energy at the country, regional, or } \\
\text { industrial and firm level }\end{array}$ & $26 \%$ & {$[6,16,43,72-106]$} \\
\hline & Electricity networks & $\begin{array}{l}\text { Interactions between distributed PV } \\
\text { providers and utilities }\end{array}$ & $4 \%$ & [107-112] \\
\hline & $\begin{array}{l}\text { Government and } \\
\text { other institutions }\end{array}$ & $\begin{array}{c}\text { Role of governments and other } \\
\text { institutions in supporting } \\
\text { PV deployment }\end{array}$ & $5 \%$ & [113-118] \\
\hline \multirow[b]{2}{*}{ Downstream } & $\begin{array}{l}\text { Closed-loop } \\
\text { supply chain }\end{array}$ & $\begin{array}{l}\text { Descriptive and modeling } \\
\text { representations of PV panels at } \\
\text { end-of-life (for reuse or recycling) }\end{array}$ & $7 \%$ & $\begin{array}{l}{[5],[119,120] *} \\
{[121-127]}\end{array}$ \\
\hline & $\begin{array}{l}\text { Performance issues and } \\
\text { environmental } \\
\text { performance of the } \\
\text { value chain }\end{array}$ & $\begin{array}{l}\text { Degradation of PV modules, life cycle } \\
\text { analysis of PV installations throughout } \\
\text { lifetime or at EOL, contribution of PV } \\
\text { towards decarbonization }\end{array}$ & $3 \%$ & [128-130] \\
\hline EV batteries & $\begin{array}{l}\text { PV systems and } \\
\text { EV batteries }\end{array}$ & $\begin{array}{c}\text { Studies combining the use of LIBs for } \\
\text { stationary PV energy storage and issues } \\
\text { at battery EOL }\end{array}$ & $14 \%$ & $\begin{array}{l}{[131-147]{ }^{*},} \\
{[148-151]}\end{array}$ \\
\hline Others & Economic modelling & $\begin{array}{l}\text { Various types of economic analyses, } \\
\text { including: cost-benefit analysis, foreign } \\
\text { trade, competing PV supply chains, } \\
\text { manufacturing plant locations, and } \\
\text { energy payback time calculations }\end{array}$ & $19 \%$ & [152-180] \\
\hline
\end{tabular}

* Cross-reference.

\subsection{Upstream PV Value Chain}

\subsubsection{Research and Development (R\&D)}

Review results show R\&D efforts in the PV industry are mostly concentrated on new material development and cell efficiency improvements (i.e., chemical process industries), as well as on specialized machinery and robotics for manufacturing [95], rather than on new recycling technologies or design for EOL. Currently, one can distinguish between three categories of PV technologies: (i) 1st generation technologies of mono- and multicrystalline silicon solar cells (c-Si); (ii) 2nd generation technologies of thin-film technologies; and (iii) newer, 3rd generation technologies of multi-junction, organic PV cells, and concentrating photovoltaics (CPV) [58,72]. Each PV technology features its own cell type, based on different semiconductor materials, module efficiency and area requirements for installation. For all technologies, large jumps in conversion efficiencies are expected in the long term. 
As an example, it is reported that the layer thickness in a CdTe (cadmium telluride) module could be reduced to around $1.0 \mu \mathrm{m}$, resulting in an efficiency gain of around $18 \%$ [50]. The same can be forecast for polycrystalline single-junction modules that could see their material intensity and weight lowered and their efficiency increased through basic research. Nowadays, almost all the leading countries in PV production (i.e., China, Japan, Germany, and the United States) devote government funds to enhancing and strengthening their basic PV research capabilities and infrastructure.

Besides the emphasis on efficiency improvements, research and implementation efforts also need to target eco-design strategies for PV to ensure, for instance, that modules are built with delamination in mind, allowing the recovery of high-quality silicon wafers at EOL. Digital technologies also play a role, not only by supporting the storage of product information, i.e., material composition and technical parameters), but also the monitoring and maintenance of PV modules for further reuse and recycling.

\subsubsection{Solar Grade Silicon Production}

Pure silicon is the dominant semiconductor material used in the production of solar cells because of its abundance, non-toxicity, high and stable cell efficiency, and the maturity of its production infrastructure [83]. Silicon is also reported as the only element that can help the PV industry achieve the number of terawatts needed for renewables to make a substantial contribution to global energy use [44]. Although this element is the second most abundant in the crust of the earth, it is not pure in its natural state and must be refined before it is used in the production of solar cells, which require high-purity silicon of at least 99.999999\% (6N).

The first reported step in the overall silicon PV production process thus involves the conversion of high-purity silica sand into silicon. The resulting metallurgical grade silicon (MG-Si), of about $98.5 \%$ purity, is obtained by the carbothermic reduction of silicates in electrode arc furnaces at temperatures above $1900{ }^{\circ} \mathrm{C}$. Most of the MG silicon at this point is used for aluminum casting or in the chemical industry. The remainder MG-Si is further refined and converted into semiconductor or solar grade silicon (SOG-Si), by using, among others, the modified Siemens process or the fluid bed reactor process $[52,92]$.

\subsubsection{Crystallization, Ingot Molding, and Wafering}

Before solar cells are manufactured, a silicon ingot is grown by different crystallization methods. Crystallization is one of the first steps in the silicon solar-cell value chain and can be differentiated by monocrystalline and poli- or multicrystalline processes $[6,51,52]$. Although multicrystalline silicon cells exhibit lower conversion efficiencies than monocrystalline ones (13-16\% vs. $15-20 \%$ ), around $56 \%$ of the world's solar cells today are produced by multicrystalline processes. This is because they are cheaper to manufacture and, thus, more preferred in the market. Once either type of silicon ingot has been manufactured, it is sliced into thin disks or wafers, and then chemically treated, doped, coated, and provided with electrical contacts in order to produce solar cells [181]. Most of the published research at this early stage of the value chain deals with examining the effects of defects and impurities on material property and ultimately on solar cell performance [44,51].

\subsubsection{Solar Cell Manufacturing}

Prior research suggests that solar cell and module manufacturing have been studied from a technological point of view only [52,169]. In this spirit, the following lines provide a quick review of the technical characteristics of silicon and thin-film solar cells.

\section{Silicon-Based}

Crystalline silicon is the most prevalent in the global market, accounting for around $90 \%$ of PV production [119]. To turn wafers into c-Si solar cells that can convert solar power into electric power, wafers are first cleaned and placed in a phosphorous diffusion furnace, resulting in a P-N junction for the photovoltaic effect. Next, the top surface of the 
wafer is covered with an anti-reflective coating to reduce the reflectivity of light and raise efficiency. Afterwards, electrical contacts are imprinted on the entire front surface of the wafer, while aluminum-based conductive material is deposited on the back surface. To finish, each cell is electrically connected to other cells to form cell circuits for assembly in PV modules $[6,52,62]$. Sets of cells or "strings" usually connect 10-12 cells in a silicon-based module and 60-100 cells in a thin-film module.

\section{Thin-Film}

Originally introduced in the 1970s, thin-film cells are an alternative PV technology aimed at reducing the cost and price of solar cells by using little or no silicon in the manufacturing process. Although they exhibit an easier manufacturing process and lower costs than c-Si cells, they also present lower light-to-voltage conversion rates (10-11\%), and therefore require more physical space to generate the same amount of power. Among the several types of thin-film cells that exist nowadays (e.g., cadmium telluride (CdTe), copper indium gallium selenide (CIGS), gallium arsenide (GaAs), and amorphous silicon (a-Si)), CdTe cells are the most prevalent [33]. Otherwise identical in structure and function, the difference between c-Si and thin-film solar cells resides in their thin and flexible layers and in the semiconductor material they use: CdTe, CIGS or GaAs instead of silicon.

The reviewed literature in connection to thin-film cells reported concerns regarding the scarcity of the base metals that make up CdTe thin-film cells (i.e., tellurium, indium, and gallium) and, therefore, on the suitability of this technology for large-scale PV deployment $[11,50]$. Some authors even suggest that the current base of critical elements in thin-film cells is not large enough to support large-scale PV deployment, even if the industry were to somehow monopolize the reserves of each element. Technological improvements involving material reduction and cheaper byproduct recovery processes, as well as circular strategies to recover critical elements from decommissioned PV panels, could offset the potential supply limitations and imminent price increases associated with the critical materials in thin-film cells.

\section{Emerging PV Cell Technologies}

Both crystalline silicon and thin-film technologies are single-junction. Multi-junction solar cells, or cells with multiple P-N junctions, promise to drastically increase solar cell efficiency because of their ability to absorb different multiple light wavelengths. Grau, Huo and Neuhoff [75] report, for instance, that for two- (tandem), three- and four-junction devices, maximum efficiencies of $55.9 \%, 63.8 \%$, and $68.8 \%$ are predicted, respectively. Besides multi-junction cells, organic materials also offer the potential for low cost and high energy absorption. These cells can be of various natures, namely: petrochemical cells, dye sensitized solar cells, organic and polymer solar cells, and other emerging technologies such as quantum dot solar cells. These technologies are still under investigation and have not yet been widely commercialized.

\subsubsection{Module Manufacturing and Balance of Systems (BOS)}

After silicon has been casted into ingots and wafers have been sliced from the ingot blocks and turned into solar cells through etching and polishing, cells are put together into modules [72]. Solar modules are the core components of PV systems and account for about $40 \%$ of the PV system price [116]. Modules are assemblies of typically $6 \times 10$ or $6 \times 12$ series-connected solar cells, which are packaged into a protective multilayered structure of five main components: (i) the front cover (tempered glass), (ii, iii and iv) the interconnected solar cells matrix in an envelope of two encapsulant layers (front/back), and (v) a back cover (back sheet or tempered glass). Such a structure provides electrical insulation and long-term protection against external environmental stresses.

Solar modules together with BOS components (e.g., inverters, batteries, controllers, and trackers) are assembled into solar PV systems by installers [62,72,116]. Of all the BOS elements, the inverter is the most important as well as the most expensive and the most 
technically complicated. An inverter transforms direct current (DC) from the PV array into a form of alternating current (AC) electricity that can be connected to the electric utility grid. Most reviewed articles concerning module manufacturing focus on the PV module manufacturing process (see Figure 6) as well as on the key technological improvements resulting in the ever-decreasing costs of silicon PV modules.

\begin{tabular}{|c|c|c|c|c|c|}
\hline Silica sand & $\begin{array}{l}\text { Metallurgical } \\
\text { silicon } \\
\text { production }\end{array}$ & $\sqrt{\begin{array}{l}\text { Poly-crystalline } \\
\text { silicon } \\
\text { production }\end{array}}$ & $\begin{array}{l}\text { Ingot molding } \\
\text { and silicon } \\
\text { wafer } \\
\text { production }\end{array}$ & $\begin{array}{l}\text { Solar cell } \\
\text { production }\end{array}$ & $\begin{array}{l}\text { Module } \\
\text { production }\end{array}$ \\
\hline
\end{tabular}

Figure 6. Manufacturing process for silicon PV modules.

\subsubsection{PV Installations}

This stage is concerned with the installation of the PV system and the delivery of electricity at the customer's premises. Small rooftop installations are typically planned by the installer, whereas larger rooftop and open space installations are handled by a planner who takes care of various aspects such as system design and installation, permit and license acquisition, construction, operation, maintenance services, insurance, and so on [72]. The few publications focusing on this particular topic highlight that the installation of a PV system is a labor-intensive process, because qualified personnel are needed to connect the solar panels and to provide after-sale services to customers [85,90]. The personnel needed for a PV installation will depend on the project size, namely whether the PV project is residential (i.e., 1-10 kW), commercial (i.e., 11-500 kW), or industrial (i.e., >500 kW). Figure 7 presents an overview of all stages in the upstream PV value chain and their relevant stakeholders.

\subsubsection{Geography and Composition of the Global PV Supply Chain}

Research showed that knowledge and technology-intensive R\&D and capital equipment segments have been traditionally located in Europe, the United States, and Japan. This scenario, however, has recently changed as many segments of the PV value chain, from polysilicon production to module manufacturing, have become part of a global value network now featuring new players such as China and Taiwan [72]. China's success in the PV industry as a rapid innovation follower has been the result of government-sponsored import-substitution policies where the infant Chinese PV industry first produced for the local market before then exporting worldwide when firms reached an international level of competitiveness $[65,72,83,89]$. Despite the new competitive landscape, low-labor, high-value added activities, such as polysilicon production and capital equipment manufacturing, are still led by European and American players [91,130].

In terms of industry structure, the supply chain for c-Si modules is described as being fragmented, because it is comprised of a plethora of firms specializing in either polysilicon feedstock, wafer, cell, or module manufacturing [52]. The articles in our sample suggest that the number of companies at the lower-end of the upstream supply chain (i.e., firms in charge of sales and installation of PV systems) exceeded those located in the upperend (i.e., suppliers of raw materials and manufacturers of wafers, ingots, and cells) [124]. However, upstream manufacturers, particularly the suppliers of capital equipment, silicon materials, and silicon wafers, provided the most value added and achieved the highest profits, because upstream activities required more firm and labor expertise, rather than standardized, routine tasks [72,89]. In contrast, manufacturers and installers of modules and panels achieved the lowest profits because barriers to entry were low and competition high [6]. 

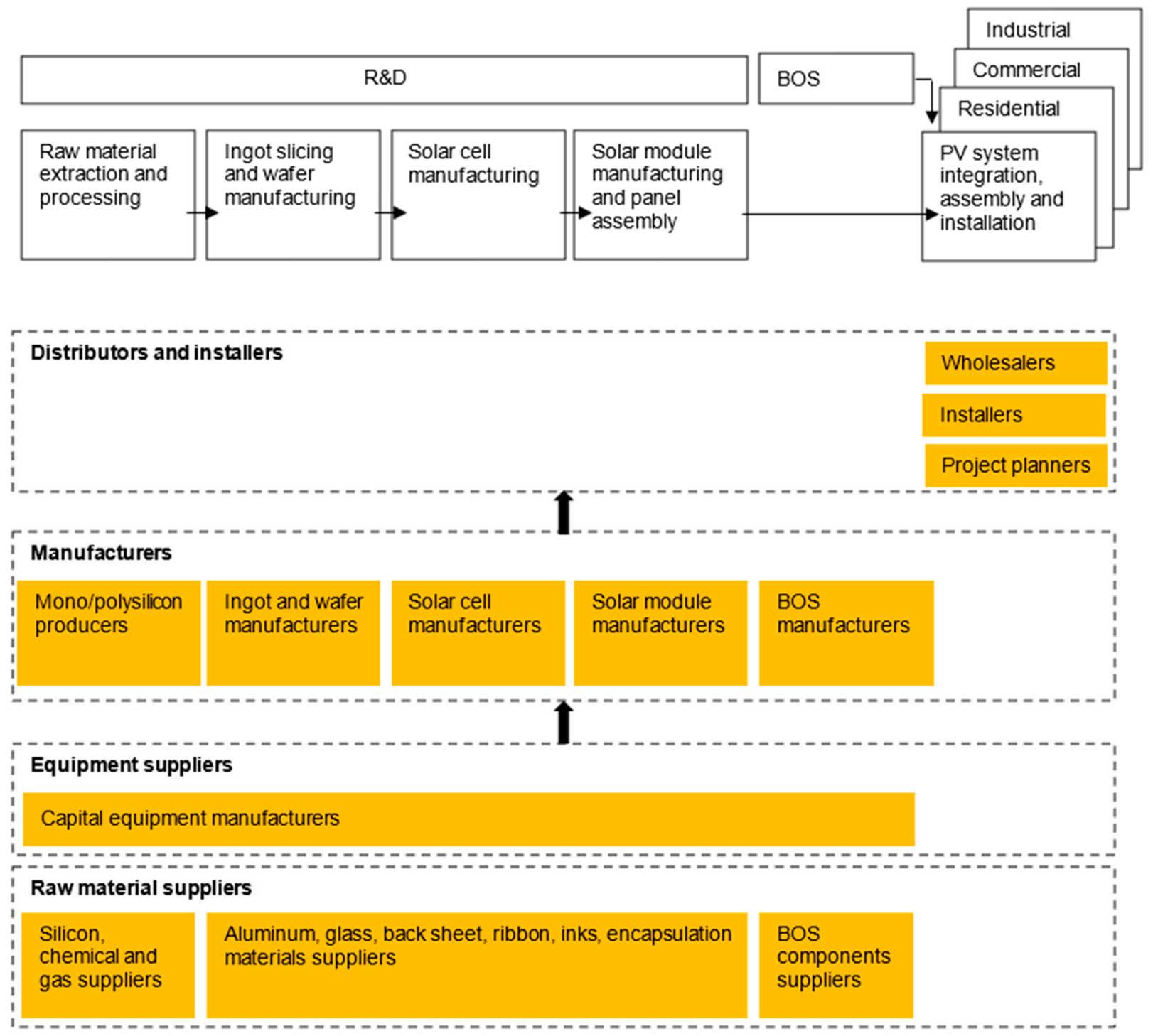

Figure 7. View of the upstream or supply side of the PV value chain.

\subsection{Midstream PV Value Chain: Business Models}

Barriers to PV system adoption, among them high up-front costs, long payback periods, and the difficulty of planning and installing a PV system, spurred the need to look for new business models (BM), or for new ways of creating, capturing, and delivering value in the industry [71,182]. The literature on business models for the PV industry was not vast. In the few identified publications, authors focused on exploring the characteristics surrounding three main PV BMs: (i) home-owned systems, (ii) third-party ownership (TPO) models, and (iii) community solar systems.

\subsubsection{Home-Owned Systems and Feed-in-Tariffs (FITs)}

In a home-owned system, customers own and finance (directly or indirectly) the upfront costs of their PV system [6] (see Figure 8). This type of business model is targeted at households and SMEs who own a sufficiently large roof (with a good solar orientation and no shadows) and have incentives to reduce the financial burden caused by high electricity costs $[69,70]$. The Netherlands, Denmark, China, and Germany are part of the fifty plus countries that have implemented FIT schemes [6]. Currently, most of the electricity generated by these home-owned systems has been connected to the grid and is reimbursed by utilities according to a regulated feed-in-tariff rate (FIT) [71]. A FIT is 
an energy-supply policy aimed at attracting investments in renewable energies by means of a payment $(\$ / \mathrm{kWh})$ to $\mathrm{PV}$ owners for any electricity that is fed back to the grid. This payment is always embedded in a long-term guaranteed purchase agreement that can last up to 25 years.

The German solar industry is reportedly a prime example of how feed-in-tariffs have helped the PV solar industry flourish. Germany, which held the world's number one place in PV installations from 2004 to 2012, was a pioneer in passing the "Renewable Energy Sources Act" (EEG) that guaranteed a minimum 20-year FIT for customers. The German EEG states that the PV electricity fed into the grid by PV installation owners has to be purchased by utility companies at an enhanced price [77]. Variations in the payment rates for FITs depend on multiple factors including energy prices, the state of the domestic electric infrastructure, and the capacity and nature of the PV installation [75].

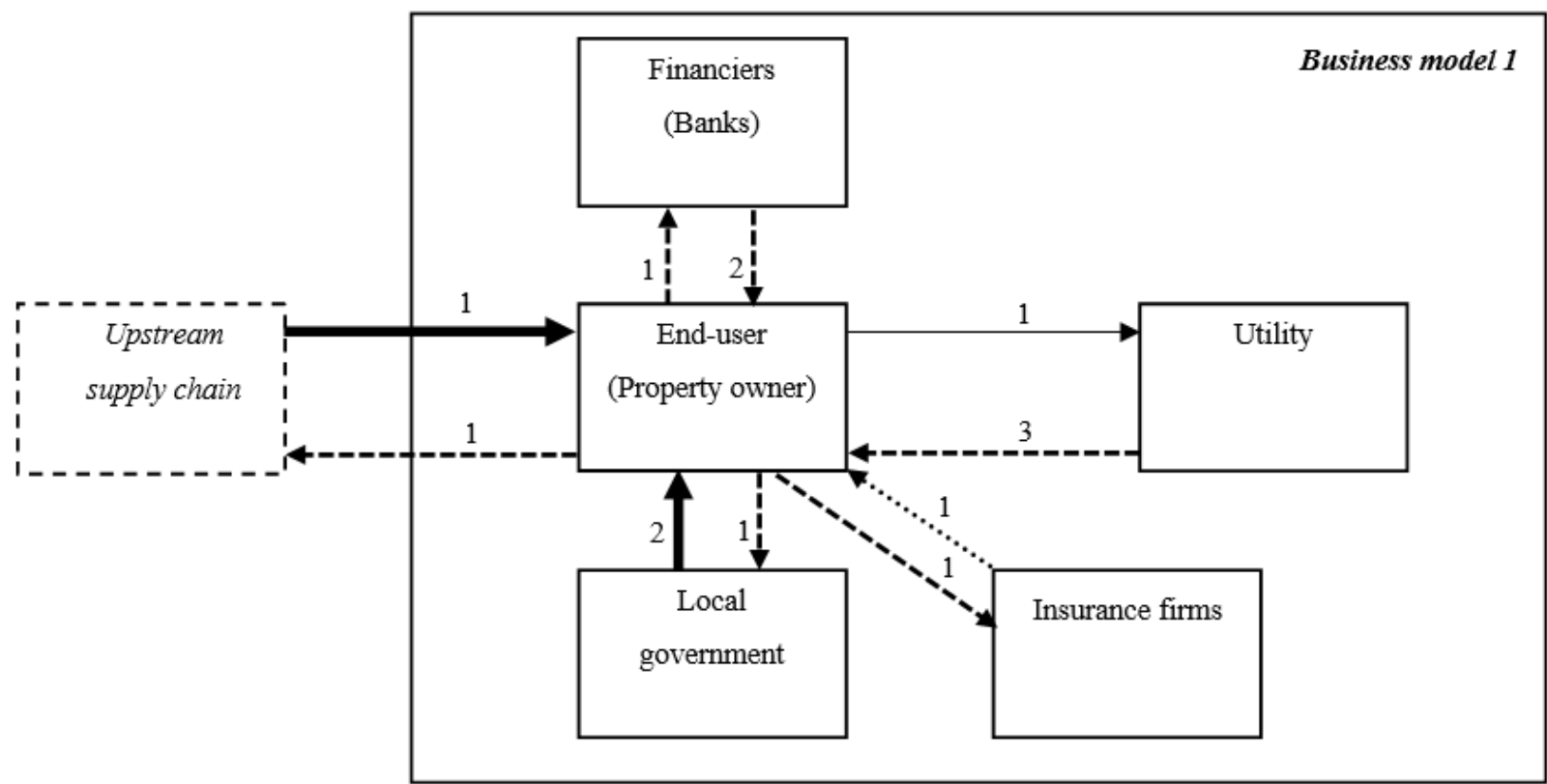

$\longrightarrow$ Material flow

$\longrightarrow$ Energy flow

--- Financial flow

$\cdots \cdots \rightarrow$ Service flow
1: PV system / 2: Installation permits and inspection

1: Excess electricity generated $(\mathrm{kWh})$

1: Payment / 2: Debt / 3: FIT payment to host

1: Services

Figure 8. Business model 1: Home-owned PV systems.

\subsubsection{Third-Party Ownership Models (TPOs)}

Third-party ownership (TPO) models were born as a response to the "high up-front costs, low operating costs" profile of PV energy provision. In a TPO model, solar service firms plan, build, own, operate, and maintain solar PV installations at the customers' premises, selling electricity to them for a predetermined period [9] (see Figure 9). Solar service companies provide a full-service solution that includes the inspection of the potential installation site, the evaluation of providers and installers (they might be the same entity), the arrangement of financing, insurance, and permits, the negotiation with utilities to sell surplus electricity to the grid, the maintenance of the solar system, and eventually the responsibility for scrapping [9]. While customers or hosts benefit by not having to deal with the high upfront costs associated with PV installations, and by passing the long-term 
operation and maintenance of the solar installation onto the TPO provider, the service provider benefits from the tax credits and revenues resulting from the sale of electricity [9].

Under a TPO model, the literature differentiates between two types of financing methods: (i) leasing and (ii) Power Purchase Agreements (PPA). In the lease model, customers (i.e., property owners or lease holders) consume the electricity generated by the PV system and pay the installer/developer a fixed monthly installment, regardless of the system's energy production. Conversely, in the PPA case, customers buy electricity from installers at a predetermined price each month, usually at a rate lower than the one offered by the local utility. This is a way for residential and business customers to incorporate predictability in volatile electricity markets. Contracts under the PPA model usually range from 15 to 25 years, after which customers can buy or return the PV system to the service provider or renew their contracts [71].

The TPO model was found to be reliant on a set of contextual conditions (e.g., tax credits, and tariffs, as well as market and consumer characteristics) that determined its financial viability and deployment trajectory in different locations [71,116]. After its particular success in the United States, other countries, such as the UK, the Netherlands, and Singapore, have implemented similar systems over the past few years $[9,56]$.
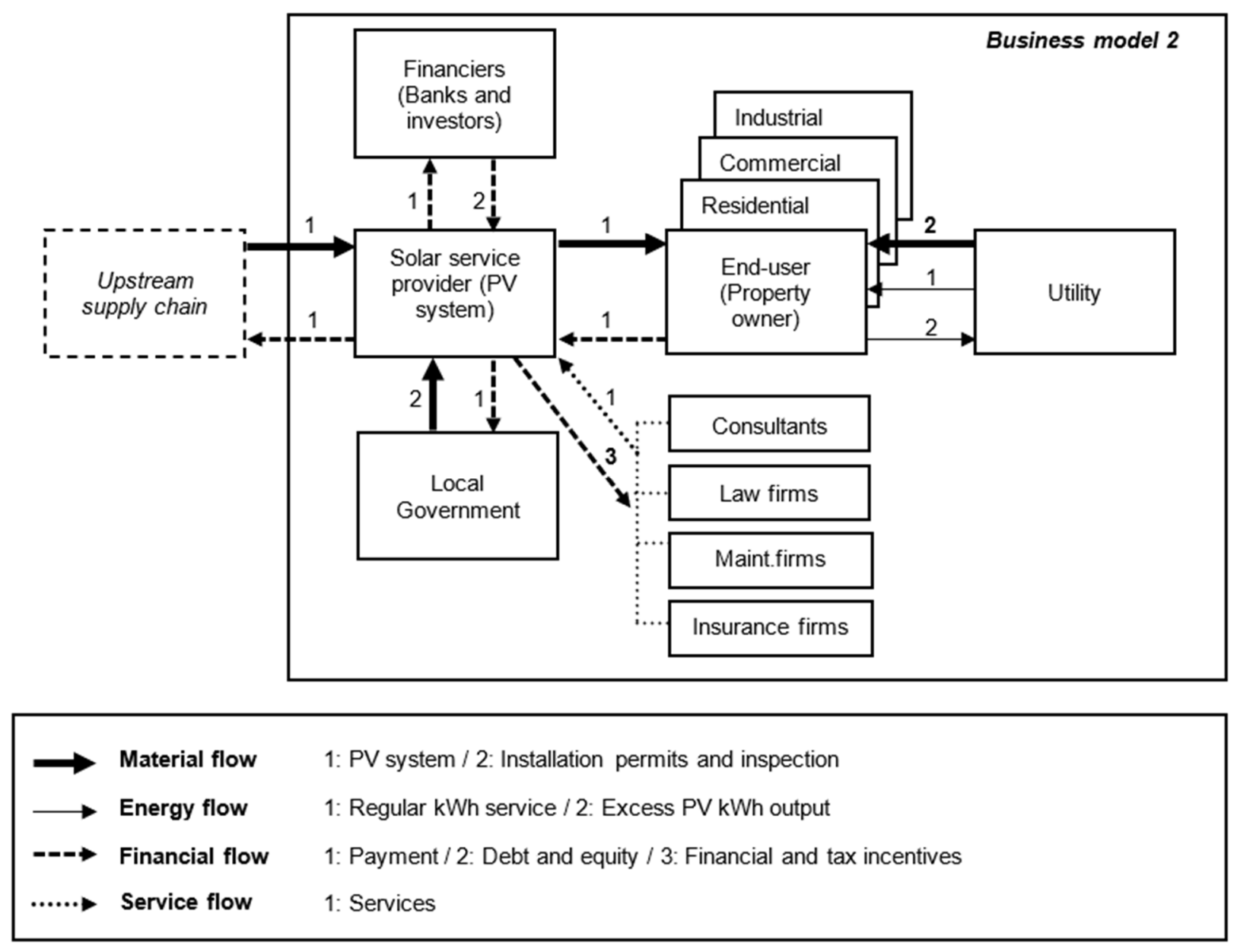

Figure 9. Business model 2: TPO model.

\subsubsection{Community Solar Model}

In a community model, multiple users purchase electricity from an off-site PV park or garden without having to host their own PV systems on-site [70]. Users that subscribe to this model either lack a suitable roof for installing a PV system (e.g., shaded, aged or damaged rooftops) or property ownership rights (e.g., people who rent or lease instead of owning, people who are planning to move). Under a community-shared business 
model, participants can purchase rights of the total output of the solar system without the need to pay any upfront costs or deal with the technical complexity of the PV installation (see Figure 10). In return, subscribers receive credit on their energy bills. Alternatively, customers can pay an upfront fee to finance the costs of the project, thereby purchasing an equity stake in the revenues from a portion of the plant [69].

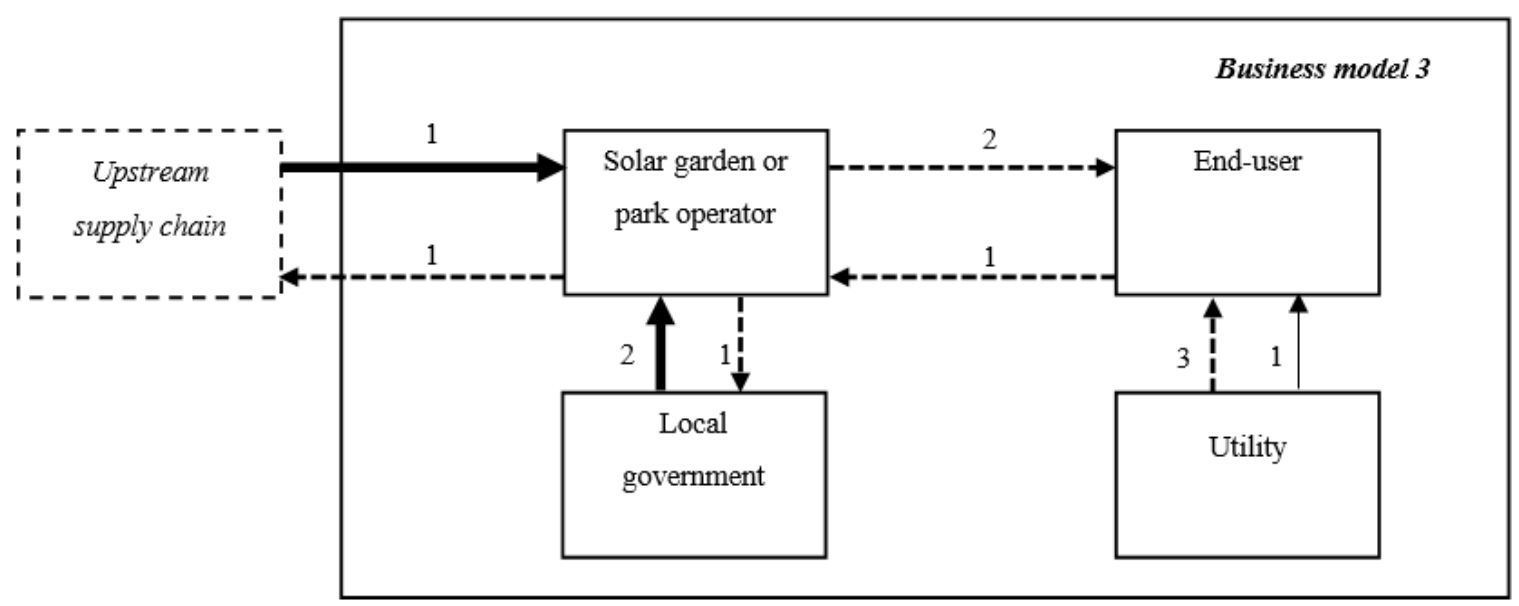

Figure 10. Business model 3: Community-solar model.

\subsection{Downstream: End-of-Life Management of PV Systems}

The appropriate end-of-life management of PV waste is of utmost importance, not only for the collection and recycling of important raw materials such as aluminum and glass, but also for the effective disposal of hazardous elements such as lead (from silicon modules) and cadmium (from thin-film modules). Growing volumes of PV waste also represent an opportunity to incorporate new value-added activities across the PV value chain and an avenue for achieving combined environmental and socio-economic benefits for multiple stakeholders. Downstream, most publications focused on PV panel recycling, with no mention of other circular strategies such as PV refurbishing or reuse.

\subsubsection{PV Panel Reuse}

Although the second life use of PV panels represents a way to slow material loops in a CE, there is no indication of significant academic research output in this area. Overall, a lack of reliable data on module degradation and yearly aging, as well as on failure rates and types, prevents relevant parties from analyzing which types of module failures warrant repair, and at what cost and performance levels. Another important unknown relates to the business case for reuse: (i) given the dramatic fall in PV module prices and increasing module efficiency over time, would consumers opt for second life modules instead of new ones? (ii) Depending on the cost structure and the technical performance of second life PV panels, which customer segments would be suitable marketing targets (e.g., residential vs. industrial customers, B2C vs. B2B, system owners pursuing the replacement of a broken module at existing installations vs. investors pursuing optimized energy output at a new, large-scale PV installations)? (iii) What would the value proposition and the value capture formula for the target customer segments be? These are questions that are yet to be investigated. 
Finally, it is not yet clear whether the definition for second life PV involves panels that are a product of warranty returns, early defects, natural disaster damage, or production scrap, just to mention a few possibilities. There is a crucial need to develop a terminology to define the state and prospective use of second life panels so policy makers and industry partners can encourage reuse and refurbishment through legislation, certifications, and industry practices.

\subsubsection{PV Panel Recycling}

As pointed out before, most R\&D funds in the PV industry have targeted improving the efficiency of crystalline silicon panels, with less effort being devoted to devising costeffective, innovative processes for dismantling and recycling PV panel waste (see Figure 11). Not much has been discussed about PV recycling because most of the PV systems that are currently in operation have only been installed since 2010. Therefore, PV waste today consists primarily either of pre-consumer waste (i.e., processing scrap from manufacturing) or decommissioned failed panels, and not of end-of-life PV modules [10,54,123]. With no substantial volume of panels to recycle, little research has been encouraged on this topic.

Current academic output in connection to recycling has mainly focused on: (i) the probability that PV panels containing recycled materials are likely to generate reduced levels of electricity, (ii) the presence of various manual activities that undermine the effectiveness of the recycling process, (iii) the probability of cross-contamination when PV waste is mixed with other types of waste [5], and finally (iv) the high dismantling, transportation, and recycling costs resulting from the presence of hazardous elements in PV panel waste [119].

In terms of regulations, the European Union introduced the EU Waste from Electrical and Electronic Equipment (WEEE) directive to regulate the collection and recovery of endof-life PV modules in 2012. The so-called "WEEE Recast" demanded that all EU member states encode the directive in national law by February 2014 and required that all PV panel manufacturers, regardless of their geographical location, finance the costs of collecting, recovering, and recycling all the PV panels sold in Europe [5,119].

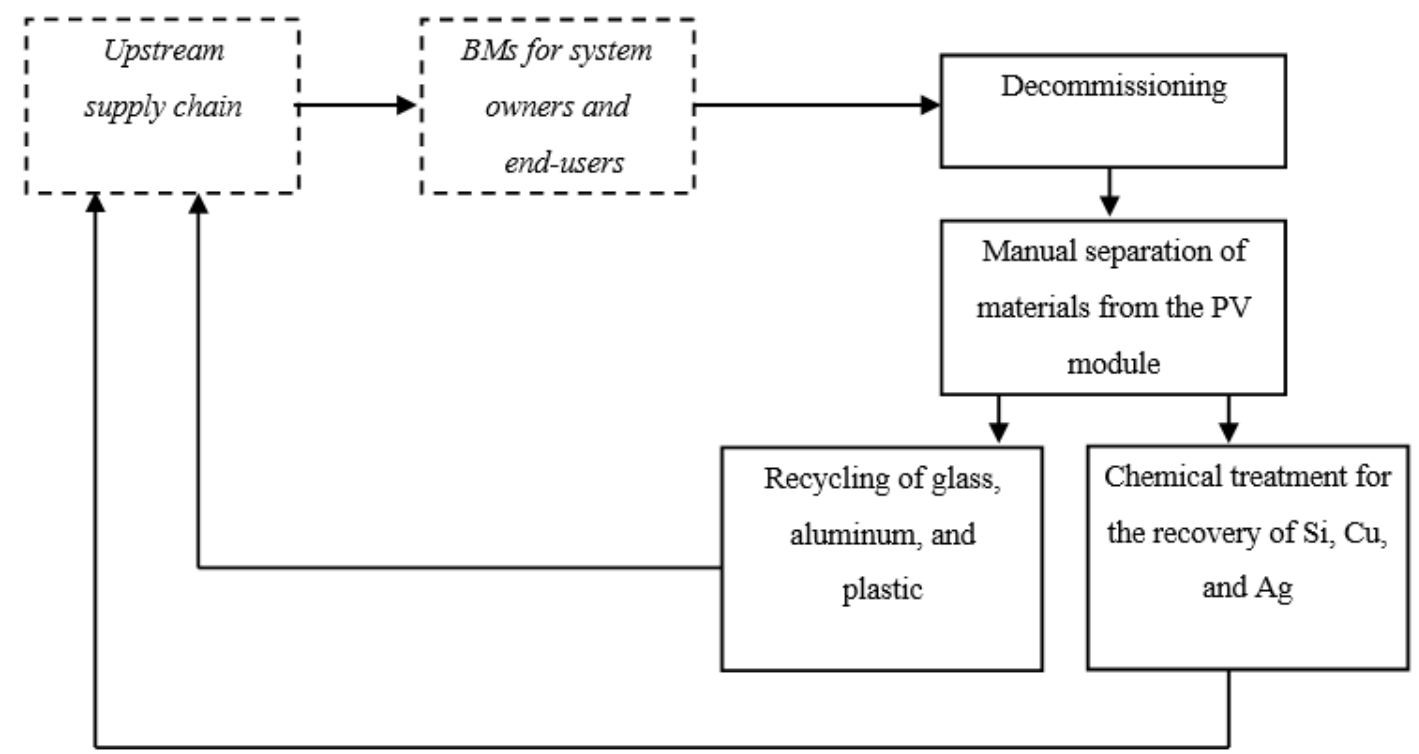

Figure 11. Recycling process for c-Si modules. Taken from [19].

Environmental Issues Related to the Disposal of PV Panels

Some of the critical environmental issues associated with the disposal of EOL PV panels include losses of scarce metals (e.g., silver, gallium, indium, and germanium) and conventional materials (e.g., aluminum and glass), plus the release of hazardous metals (e.g., cadmium, lead, tellurium, and selenium) and toxic gases (e.g., hydrofluoric acid) into 
the environment [119-121]. The leaching of hazardous materials such as $\mathrm{Pb}$ and $\mathrm{Cd}$, which takes place when the glass that encapsulates the PV cells is broken down or damaged, has been of particular concern [119]. Cadmium, for instance, is believed to cause itai-itai disease and to be toxic to fish and wildlife, as well as to the human body. Once absorbed, cadmium can cause lung, kidney, and bone damage [124].

Furthermore, many elements critical to emerging PV technologies, such as indium, tellurium, and gallium, today exhibit near-zero recycling rates [12]. Indium, for instance, is present in amorphous silicon and copper indium gallium selenide panels, while gallium is present in copper indium gallium selenide panels, concentrated photovoltaic panels, and other emerging panel technologies [119]. Although these metals account for about $1 \%$ of the panel volume, their value is significant, and their non-recirculation would signify a loss for manufacturers and the industry in general. The main challenge is to find methods that allow for recovery at the highest possible purity level.

\section{Cost}

Various authors report on the loss of profitability that will result from recycling PV panels. Current low volumes of decommissioned panels not only make recycling expensive, but also decrease the incentives that manufacturers have to proactively engage in recovery and recycling schemes [5]. High collection, dismantling, transportation, and capital costs (including machinery, chemicals, and other materials) associated with establishing recycling infrastructure mean that it is not economical to recycle at low waste volumes today. High recycling costs also increase competition for landfilling (i.e., it is cheaper to landfill than to recycle) and the incentives for low value recycling (i.e., no material separation before recycling). The question is also whether the recovery of certain precious materials might profitably offset overall recovery costs, thereby supporting the competitive position of PV manufacturers and PV technologies.

\subsection{Electric Vehicle (EV) Batteries for PV Energy Storage}

Giving electric vehicle batteries a second life as a stationary unit for renewable energy storage not only helps the PV industry become more circular, but it also prolongs the lifespan of batteries (through reuse) and delays costly recycling by 3-15 years. Lithium-ion batteries (LIBs) are removed from the EV when their maximum capacity has degraded to $70-80 \%$ of the original capacity, which occurs about $8-10$ years after the vehicle has entered into operation [139]. At this point, when the vehicle is no longer suitable for automotive purposes, EV batteries can be re-purposed and given a second life use in less stressful applications such as stationary storage units for PV energy [149]. A business model that couples PV technology with storage devices could help fit intermittent renewable technologies into the existing power generation system and increase solar energy dispatchability (see Figure 12).

According to the few articles that simultaneously discuss LIBs and PV systems, the second life use of LIBs can only be accomplished once some issues are resolved. This would specifically involve: (i) finding out what the costs of refurbishing an EV battery are; (ii) dealing with the uncertainty surrounding the reduction in capacity or efficiency of the LIB after its first life; and (iii) dealing with warranties, reliability and safety concerns, as well as regulatory barriers that hinder customer trust and the adoption of second life LIBs $[140,146]$. A separate study that details the EV battery value chain could shed light on more concrete answers to such questions. 
Repurposing methods

Direct use / Module dismantle / Cell dismantle

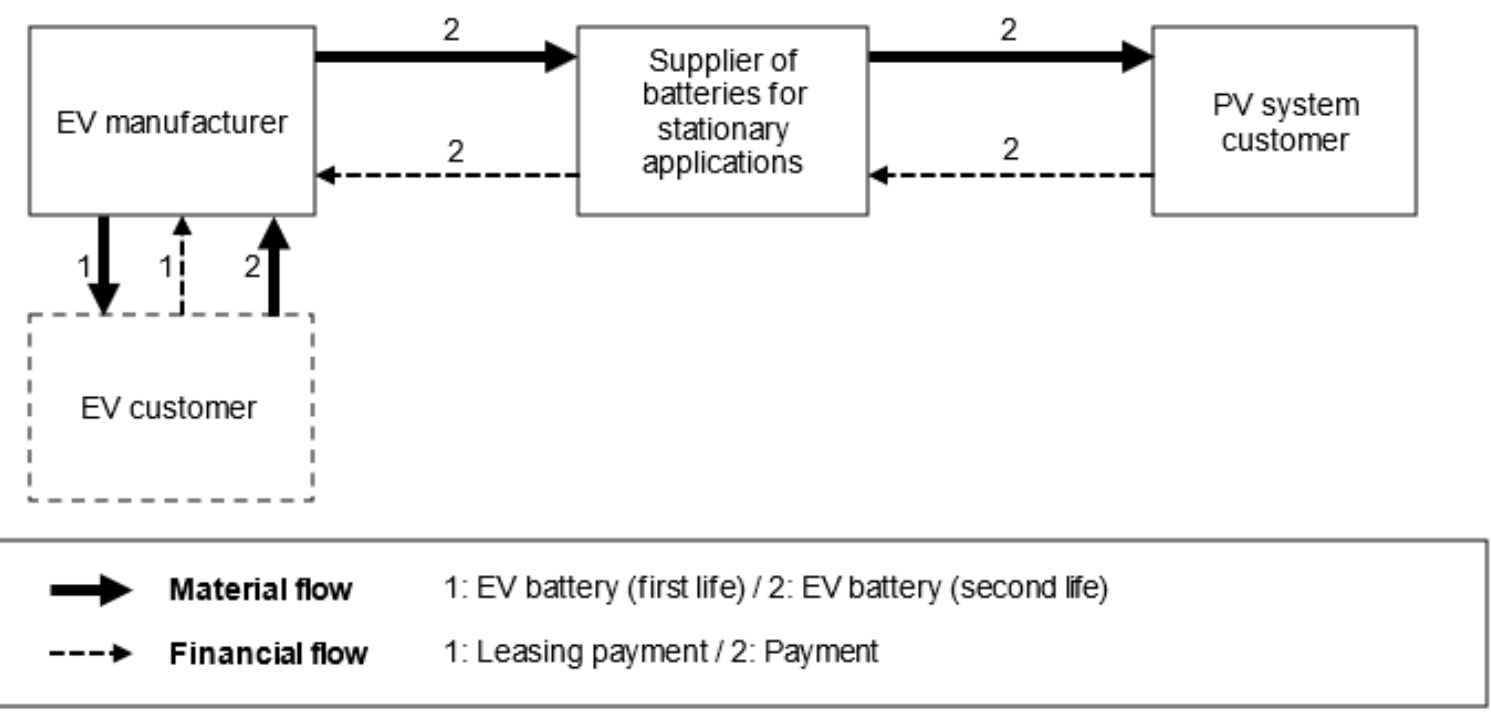

Figure 12. Repurposing flow for second life LIBs.

\section{Discussion and Conclusions}

Photovoltaic installations have experienced explosive growth globally following the increasing attention of industry and policy on climate change mitigation, the decarbonization and diversification of the energy sector, and energy security. The expected expansion of global solar PV generation capacity will inevitably translate into a large volume of solar panel waste in the future. A similar growth/waste scenario is expected for lithium-ion batteries, which end their automotive life when their maximum capacity has degraded to $70-80 \%$ of their original capacity.

In this article, we posit that a closer look at the current functioning and structure of the PV value chain is necessary to highlight critical improvement areas to achieve circularity in the PV industry. To paint a more refined picture of the PV value chain, we conducted a systematic literature review based on 148 articles published between 2000 and 2020 . Results showed that most of the academic research output related to the studied topic has: (i) increased since 2013; (ii) been primarily published by European research institutions, with Germany, the United Kingdom, and Italy at the forefront; and (iii) been technologyfocused, concentrating on ways to achieve more efficient and competitive, brand-new PV systems. Furthermore, almost all the papers that matched the search criteria for the SLR provided a narrow view, describing the PV value chain as starting with raw material procurement and ending with the installation of PV systems at the customers' premises.

Table 7 provides a summary of some of the main issues, in connection with circularity and throughout each stage of the PV value chain, that emerged during the SLR. These issues can be understood as barriers to circularity from an industry perspective and have been classified according to different criteria, such as technical, financial, customer-related, and infrastructure-related. Upstream, both the PV and the EV industry allocate R\&D funds for efficiency improvements in the asset's first life, disregarding investments in design of easier-to-recover panels or more cost-effective recycling technologies. Ensuing module circularity and smartness to enable module repairability (e.g., replacement of bypass diodes in the junction box or the complete junction box), dismantlability (e.g., separation and recovery of the semiconductor from the frame, glass, encapsulants and back sheet) and material disclosure (e.g., metals and polymers) should be a priority for industry players and policymakers if circularity in PV is to be achieved.

Midstream in the PV value chain, business models catered to the needs of brand-new PV system owners only, e.g., home-owned, with no mention of innovative business models 
supporting the deployment of second life modules decommissioned due to technical failures, insurance claims, repowering or early replacement. BMs that enable the diffusion of second-hand PV modules in low-income economies, where the low-cost feature could compensate for the lower remaining lifetime and lower performance of used modules, could be an alternative. Because of their geographical location, developing countries tend to be greatly endowed with renewable resources, including solar irradiation. Tighter budgets, lower requirements for panel aesthetics, increased tolerance towards modules with no warranties, and the need for still efficient, yet affordable modules, make second life PV a suitable option for low-income areas that lack access to grid electricity. Examples of use cases include not only home energy applications, battery charging and solar Wi-Fi, but also solar irrigation and refrigeration for agriculture. The latter are particularly critical for developing countries, where households rely on small-scale agriculture for sustenance, income, or both. All in all, off-grid solar solutions represent a clean energy alternative to replace environmentally harmful energy sources (e.g., charcoal from fuelwood) and reduce carbon-related emissions, increase rural electrification levels, and help provide incomeenhancing opportunities and raise living standards for disadvantaged communities. Recent environmental and health-related shocks are also a reminder of the need for establishing off-grid energy preparedness to increase self-sufficiency and systemic resilience for energy provision. This is especially true in the mentioned areas where the impact of such shocks tends to be of a higher magnitude.

We also highlight the fact that scarce statistical data on PV module failures and the costs of the corresponding repairs hinder the emergence of BMs for PV and battery reuse. We therefore believe that additional research is necessary to more accurately estimate not only the possible volume trajectories of second life PV and EOL waste but also the levelized cost of electricity (LCOE) (i.e., the net present value of the total cost of a system divided by the total amount of energy it produces) for both new and second life PV and batteries. Only when a second life PV system has a LCOE that is lower or at least the same as the LCOE of a system with new panels, is it financially attractive for customers in all market segments. With decreasing costs and increased efficiencies for newer PV panel technologies, one could argue that new PV systems will be the preferred choice in developed economies, where consumers rely heavily on high efficiency, aesthetics, and warranties. If this is the case, and early replacement takes place, volumes of decommissioned PV panels will be higher than expected. Finally, business models dealing with new PV systems were found to be contextual and adapted to the market needs and regulatory landscape of the country where they were the most prevalent (e.g., home-owned systems in Germany or third-party ownership models in the United States).

At the downstream end of the PV value chain, lack of design for refurbishing, disassembly, and recycling, current low volumes EOL panel waste, differences in PV panel architectures, and infant recycling technologies and infrastructure, currently turn PV recycling into an unattractive and unprofitable activity for manufacturers and recyclers. Similarly, low volumes of waste combined with different battery chemistries and configurations, as well as uncertainties surrounding the economic, technical, and environmental viability of repurposed EV batteries for energy storage, represent some of the main hurdles to the cost-efficient deployment of EV batteries for second life. When these uncertainties are eliminated, public policy could support the development of certification schemes that can boost customer trust and accelerate market adoption for both second life PV and LIBs. Finally, the barriers presented in Table 7 evidence the extent to which, from the perspective of the customer, both intrinsic (e.g., knowledge and perception of circular products) and extrinsic attributes (e.g., product infrastructure, pricing, warranties) must be addressed if the diffusion of circular business models in the PV industry is to be secured. All in all, we posit that value chain challenges and barriers can be taken as opportunities for the creation of future innovative value formulas and policies that address current technical, socio-economic and regulatory hurdles. 
Table 7. Summary of CE-related challenges derived from the SLR.

- $\quad$ Accurate data on PV panel failure (e.g., failure types and rates, performance after

repair, and repair costs) are still a work-in-progress, due to the low volume of

decommissioned PV panels
do the low volume of and infant PV monitoring and infant PV monitoring however, some technological solutions for fault finding and tracking are under research) [20] proper separation of PV EOL

- Manufacturers optimize product design for first life, not for use thereafter (i.e. design for disassembly, refurbishment, and

Technical

- R\&D activities concentrate on material technologies and cell efficiency improvements, rather than design for EOL

- $\quad$ All possible diffusion paths of the different PV technologies are key limitations to forecasting the trajectory of solar energy production and storage
- Business models are designed for brand new $\mathrm{PV}$ system owners. New BMs for second life and recycled PV and LIBs are therefore needed

- $\quad$ All the unknowns associated with second life PV and LIBs (e.g., cost performance, volum
interfere with the interfere with the
development of innovative value proposition package for new business models

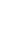

LIBs is demanding as each cell needs to be controlled and the BMS needs to be set up to fit the battery's new

surroundings and application

There is uncertainty about the remaining battery capacity after its use in first ${ }^{t}$ life (i.e. the ageing performance of second life batteries)

- Most tests measuring the efficiency and longevity of LIBs for stationary energy storage have been performed as demonstrations at the laboratory level only

- Lack of coordination and collaboration between producers and recyclers

- Lack of proper material recovery technologies. Many pilot projects are underway to improve the efficiency of different recycling methods

- $\quad$ Lack of sufficient recycling

infrastructure

- $\quad$ PV panels contain toxic chemicals (e.g., $\mathrm{Pb}, \mathrm{Cd}, \mathrm{Cr}$ ) that cannot be removed without breaking apart the entire panel. When the PV cells are separated from the glass that contains them, hazardous substances are likely to be

- When landfilled, PV panels can break and leach toxic chemicals and gases into the environment
- $\quad$ released into the environment handling, the disassembly of aluminum frames and other aluminum components in the PV panel is highly manual. This limits the efficiency of the recycling process

- Many elements critical to emerging PV technologies, such as indium, tellurium, and gallium exhibit near-zero recycling rates

- There are concerns about the performance of PV panels manufactured out of recycled materials (i.e., the more the recycled material in new PV panels, the greater the probability of lower levels of electricity generation)

- The non-disclosure of proprietary product information and differen material combinations in PV panels complicate the recycling process 
Table 7. Cont.

- Current BMs do not provide avenues or incentives to refurbish or recycle PV panels

- Customers might perceive refurbished or recycled products as exhibiting lower performance

Custome

- $\quad$ Dropping prices an increased efficiency of new PV panel generations may lead to earlier panel replacement than what it is expected

- The transport of LIBs is costly

\section{Infrastructure}

- $\quad$ Although the recycling of PV panels is expected to $\mathrm{PV}$ panels is expected to
decrease the economic costs associated with their production, there is still no realignment of operations or asset prices based on recycled materials and highly regulated because it can be considered as hazardous waste

- Warranties, reliability, and safety concerns of second life $\mathrm{PV}$ and LIBs hinder customer trust and product adoption

- If second life battery storage how will grid infrastructure be affected? (in terms of its capacity for external connections) is pursued on a massive scale,
- Although some OEMs have implemented take back systems, adequate collection systems/plants are lacking

- $\quad$ PV panels are manufactured in key locations, but they are geographically dispersed across the globe
- Lack of awareness and/or poor market confidence in refurbished/recycled PV panels
- Lack of adequate collection centers and recycling systems and plants

- $\quad$ Risk of overinvesting in capacity due to the uncertainty in the material composition of future technologies and the difficulty in determining future PV waste volumes

- Due to the low volume of decommissioned PV systems and EV batteries, there is a lack of evidential data on the costs of collecting, dismantling, and collecting, dismantling, and
recycling both types of systems

- The recycling of EOL PV panels is currently not profitable (high transportation, collection, and infrastructure costs vs. low volumes of waste) 
Table 7. Cont.

- The profitability of recycling also depends on the technology. For instance, thin-film technologies promise higher profit thanks to

the presence of precious materials.

In the case of c-Si panels, the

absence of valuable metals/materials produces economic losses

- Many consumers and OEMs prefer landfill if it is cheaper than recycling

- With higher cell efficiencies and lower material prices expected in the future: will the recycling of PV panels make econo

- $\quad$ Legislation for second life use of LIBs has not been

developed in the EU. There

has to be a business case fo

reuse rather than recycling

- Will regulations at the loca

level (e.g., FITs that enable

- $\quad$ Undefined roles of producer responsibility throughout the the sale of excess solar powe to the grid) minimize the

financial benefits of energy storage?
- $\quad$ Lack of proper government regulation (recovery targets and responsibilities along the value chain) 


\section{Future Research}

In the previous sections we identified and discussed different research streams related to the echelons of the PV value chain. Based on these results, it became clear that published literature has studied the PV industry in a fragmented manner and often from a purely technological standpoint. Although the technical aspects of PV and LIB technologies are critical, and certainly warrant further research efforts, more socio-economic analyses connecting some of interacting segments of the value chain might provide a more holistic and dynamic view of the industry in the short, medium, and long term. In this section, we raise some key questions based on the belief that a holistic and dynamic view of the industry is the most effective strategy to guide future research and to prevent researchers from making unnecessary deviations. We suggest future studies could, for instance, address the following questions:

- What will be the impacts of raw material scarcity, price fluctuations, or other external shocks such as pandemics or extreme weather events on the resilience of the PV and battery supply chain? Additionally, what are the implications of scarcity and fluctuating prices for R\&D activities and high-value material recovery activities at EOL (i.e., at the raw material stage)?

- Which PV technologies and battery chemistries will triumph over others in the quest to dominate market share over the medium and the long term? Additionally, what are the effects of these trajectories on the adoption, uptake, second life use, and decommissioning of PV systems and LIBs (i.e., PV and EV battery cell/module manufacturing stage)?

- How will the mix of dominant PV and battery technologies affect different policy options and industry arrangements for the deployment of innovative business models (that facilitate monitoring, collection, reuse, and recycling)? How do new BMs create simultaneous value for manufacturers, service providers, end-customers, and utilities (i.e., at the deployment and business model stage)?

- For both reuse and recycling scenarios, what are the estimated recovery rates, costs, and performance indicators for each PV technology? Additionally, at what rate will the recovered materials be used in new manufacturing cycles? Moreover, with new "circular tasks" to be performed (i.e., refurbishment for reuse, recycling, and so on) new ecosystem actors are likely to emerge. If so, what will be the nature of the work performed by these actors and what is their connection with the traditional actor network of the PV and LIB value chain (i.e., circular economy strategies)?

Given the complexity of a circular PV industry, answering some of these questions with the aid of quantitative complex system methods such as system dynamics or agent-based modelling might be appropriate. These tools have the power to capture the many dynamic relationships (e.g., feedbacks, non-linearities, individual actor behavior) and the various impact types (e.g., social, environmental, and economic) inherent in PV and EV value chains. For instance, a time-dependent analysis of how price changes in conventional and alternative energy sources, coupled with how different business models and government policies, as well as customer-related behavioral factors, affect the competitiveness of the PV industry, the uptake of different PV technologies, and the subsequently available resource types and qualities for reuse, refurbishment, and recycling, is a concrete example of a modelling application. Additionally, simulation models could not only enhance understanding about different industry development scenarios but could also help identify key circularity metrics at the firm and industry level.

Supplementary Materials: The following are available online at https:/ /www.mdpi.com/article/10 $.3390 / \mathrm{su} 13179615 / \mathrm{s} 1$, an Excel file with a record of all the reviewed publications can be found as supplementary data to this article.

Author Contributions: Conceptualization, methodology, and software, M.A.F. and S.N.G.; formal analysis and original draft preparation, as well as writing, reviewing and editing, M.A.F.; funding 
acquisition, project administration, and article proof-reading, S.N.G. All authors have read and agreed to the published version of the manuscript.

Funding: This research has received funding from the European Union's Horizon 2020 research and innovation programme CIRCUSOL under grant agreement No 776680.

Institutional Review Board Statement: Not applicable.

Informed Consent Statement: Not applicable.

Data Availability Statement: Not applicable.

Acknowledgments: We are thankful to all CIRCUSOL partners for their initial feedback on the content of this article, as well as to the anonymous reviewers, whose comments and suggestions helped improve and clarify this manuscript.

Conflicts of Interest: The authors declare no conflict of interest.

\section{Abbreviations}

$\begin{array}{ll}\text { AC } & \text { Alternating current } \\ \text { BESS } & \text { Battery energy storage systems } \\ \text { BEV } & \text { Battery electric vehicle } \\ \text { BMs } & \text { Business models } \\ \text { BMS } & \text { Battery management system } \\ \mathrm{C} & \text { Carbon } \\ \mathrm{Cd} & \text { Cadmium } \\ \mathrm{CdTe} & \text { Cadmium telluride } \\ \mathrm{CE} & \text { Circular economy } \\ \mathrm{Co} & \text { Cobalt } \\ \mathrm{CO} 2 & \text { Carbon dioxide } \\ \mathrm{Cr} & \text { Chromium } \\ \mathrm{c}-\mathrm{Si} & \text { Crystalline silicon } \\ \mathrm{CSP} & \text { Concentrating solar power } \\ \mathrm{Cu} & \text { Copper } \\ \mathrm{DC} & \text { Direct current } \\ \mathrm{EOL} & \text { End-of-life } \\ \mathrm{EV} & \text { Electric vehicle } \\ \mathrm{FIT} & \text { Feed-in-tariff } \\ \mathrm{GW} & \text { Gigawatts } \\ \mathrm{GWh} & \text { Gigawatt hours } \\ \text { LbD } & \text { Learning by doing } \\ \text { LIB } / \text { Li-ion } & \text { Lithium-ion battery } \\ \mathrm{mc}-\mathrm{Si} & \text { Multicrystalline silicon } \\ \mathrm{MG-Si} & \text { Metallurgical-grade silicon } \\ \mathrm{MW} & \text { Megawatt } \\ \mathrm{N} / \mathrm{A} & \text { Not available } \\ \mathrm{OEM} & \text { Original equipment manufacturer } \\ \mathrm{Pb} & \text { Lead } \\ \mathrm{PPA} & \text { Power purchase agreement } \\ \mathrm{PV} & \text { Photovoltaic } \\ \mathrm{R} \& \mathrm{D} & \text { Research and development } \\ \mathrm{SLR} & \text { Systematic literature review } \\ \mathrm{SOG}-\mathrm{Si} & \text { Solar-grade silicon } \\ \mathrm{TPO} & \text { Third-party owned } \\ \mathrm{WEEE} & \text { Waste electrical and electronic equipment } \\ & \end{array}$

\section{References}

1. IRENA. Future of Solar Photovoltaic: Deployment, investment, technology, grid integration and socio-economic aspects. Glob. Energy Transform. Pap. 2019.

2. IRENA. Global Energy Transformation: A Roadmap to 2050, 2019 ed.; IRENA: Abu Dhabi, United Arab Emirates, 2019. 
3. IRENA. End-of-Life Management: Solar Photovoltaic Panels International Renewable Energy Agency. 2016. Available online: http: / / www.irena.org/DocumentDownloads/Publications/IRENA_IEAPVPS_End-of-Life_Solar_PV_Panels_2016.pdf (accessed on 8 September 2018).

4. Kumar, A.; Holuszko, M.; Espinosa, D.C.R. E-waste: An overview on generation, collection, legislation and recycling practices. Resour. Conserv. Recy. 2017, 122, 32-42. [CrossRef]

5. Besiou, M.; Wassenhove, L.N. Closed-Loop Supply Chains for Photovoltaic Panels: A Case-Based Approach. J. Ind. Ecol. 2016, 20, 929-937. [CrossRef]

6. Jia, F.; Sun, H.; Koh, L. Global solar photovoltaic industry: An overview and national competitiveness of Taiwan. J. Clean. Prod. 2016, 126, 550-562. [CrossRef]

7. Olson, E.L. Green Innovation Value Chain analysis of PV solar power. J. Clean. Prod. 2014, 64, 73-80. [CrossRef]

8. Zobel, A.-K.; Balsmeier, B.; Chesbrough, H. Does patenting help or hinder open innovation? Evidence from new entrants in the solar industry. Ind. Corp. Chang. 2016, 25, 307-331. [CrossRef]

9. Overholm, H. Collectively created opportunities in emerging ecosystems: The case of solar service ventures. Technovation 2015, 39, 14-25. [CrossRef]

10. Sica, D.; Malandrino, O.; Supino, S.; Testa, M.; Lucchetti, M.C. Management of end-of-life photovoltaic panels as a step towards a circular economy. Renew. Sustain. Energy Rev. 2018, 82, 2934-2945. [CrossRef]

11. Bustamante, M.L.; Gaustad, G. Challenges in assessment of clean energy supply-chains based on byproduct minerals: A case study of tellurium use in thin film photovoltaics. Appl. Energy 2014, 123, 397-414. [CrossRef]

12. Gaustad, G.; Krystofik, M.; Bustamante, M.; Badami, K. Circular economy strategies for mitigating critical material supply issues. Resour. Conserv. Recy. 2018, 135, 24-33. [CrossRef]

13. Kaplinsky, R.; Morris, M. A Handbook for Value Chain Research; International Development Research Centre: Ottawa, ON, Canada, 2001.

14. Porter, M.E. Competitive Strategy: Techniques for Analyzing Industries and Competitors; Schuster, S., Ed.; Free Press: New York, NY, USA, 2008.

15. Yan, L.; Wang, A. Based on material flow analysis: Value chain analysis of China iron resources. Resour. Conserv. Recy. 2014, 91, 52-61. [CrossRef]

16. Kim, K.; Lee, S. How Can Big Data Complement Expert Analysis? A Value Chain Case Study. Sustainability 2018, 10, 709. [CrossRef]

17. D'heur, M. Sustainable Value Chain Management; Springer International Publishing: Cham, Switzerland, 2015.

18. Fonteyn, P.; Lizin, S.; Maes, W. The evolution of the most important research topics in organic and perovskite solar cell research from 2008 to 2017: A bibliometric literature review using bibliographic coupling analysis. Sol. Energy Mater. Sol. Cells 2020, 207, 110325. [CrossRef]

19. Theelen, M.; Daume, F. Stability of Cu (In,Ga)Se2 solar cells: A literature review. Sol. Energy 2016, 133, 586-627. [CrossRef]

20. Osterwald, C.R.; McMahon, T.J. History of accelerated and qualification testing of terrestrial photovoltaic modules: A literature review. Prog. Photovolt. Res. Appl. 2009, 17, 11-33. [CrossRef]

21. Shubbak, M.H. Advances in solar photovoltaics: Technology review and patent trends. Renew. Sustain. Energy Rev. 2019, 115, 109383. [CrossRef]

22. Pawluk, R.E.; Chen, Y.; She, Y. Photovoltaic electricity generation loss due to snow-A literature review on influence factors, estimation, and mitigation. Renew. Sustain. Energy Rev. 2019, 107, 171-182. [CrossRef]

23. Ndiaye, A.; Charki, A.; Kobi, A.; Kébé, C.M.F.; Ndiaye, P.A.; Sambou, V. Degradations of silicon photovoltaic modules: A literature review. Sol. Energy 2013, 96, 140-151. [CrossRef]

24. Sanz Saiz, C.; Polo Martínez, J.; Martín Chivelet, N. Influence of Pollen on Solar Photovoltaic Energy: Literature Review and Experimental Testing with Pollen. Appl. Sci. 2020, 10, 4733. [CrossRef]

25. De Freitas Viscondi, G.; Alves-Souza, S.N. A Systematic Literature Review on big data for solar photovoltaic electricity generation forecasting. Sustain. Energy Technol. Assess. 2019, 31, 54-63. [CrossRef]

26. Qazi, A.; Fayaz, H.; Wadi, A.; Raj, R.G.; Rahim, N.A.; Khan, W.A. The artificial neural network for solar radiation prediction and designing solar systems: A systematic literature review. J. Clean. Prod. 2015, 104, 1-12. [CrossRef]

27. Kurukuru, V.S.B.; Haque, A.; Khan, M.A.; Sahoo, S.; Malik, A.; Blaabjerg, F. A Review on Artificial Intelligence Applications for Grid-Connected Solar Photovoltaic Systems. Energies 2021, 14, 4690. [CrossRef]

28. Nain, P.; Kumar, A. Initial metal contents and leaching rate constants of metals leached from end-of-life solar photovoltaic waste: An integrative literature review and analysis. Renew. Sustain. Energy Rev. 2020, 119, 109592. [CrossRef]

29. Nain, P.; Kumar, A. Understanding the possibility of material release from end-of-life solar modules: A study based on literature review and survey analysis. Renew. Energy 2020, 160, 903-918. [CrossRef]

30. Kihlström, V.; Elbe, J. Constructing Markets for Solar Energy-A Review of Literature about Market Barriers and Government Responses. Sustainability 2021, 13, 3273. [CrossRef]

31. Lazdins, R.; Mutule, A.; Zalostiba, D. PV Energy Communities-Challenges and Barriers from a Consumer Perspective: A Literature Review. Energies 2021, 14, 4873. [CrossRef]

32. Alipour, M.; Salim, H.; Stewart, R.A.; Sahin, O. Predictors, taxonomy of predictors, and correlations of predictors with the decision behaviour of residential solar photovoltaics adoption: A review. Renew. Sustain. Energy Rev. 2020, 123, 109749. [CrossRef] 
33. Sampaio, P.G.V.; González, M.O.A. Photovoltaic solar energy: Conceptual framework. Renew. Sustain. Energy Rev. 2017, 74, 590-601. [CrossRef]

34. Mahmoudi, S.; Huda, N.; Alavi, Z.; Islam, M.T.; Behnia, M. End-of-life photovoltaic modules: A systematic quantitative literature review. Resour. Conserv. Recy. 2019, 146,1-16. [CrossRef]

35. Salim, H.K.; Stewart, R.A.; Sahin, O.; Dudley, M. Drivers, barriers and enablers to end-of-life management of solar photovoltaic and battery energy storage systems: A systematic literature review. J. Clean. Prod. 2019, 211, 537-554. [CrossRef]

36. Denyer, D.; Tranfield, D. Producing a systematic review. In The Sage Handbook of Organizational Research Methods; Buchanan, D., Bryman, A., Eds.; Sage Publications Ltd.: London, UK, 2009; pp. 671-689.

37. Tranfield, D.; Denyer, D.; Smart, P. Towards a Methodology for Developing Evidence-Informed Management Knowledge by Means of Systematic Review. Br. J. Manag. 2003, 14, 207-222. [CrossRef]

38. Cook, D.J.; Mulrow, C.D.; Haynes, R.B. Systematic reviews: Synthesis of best evidence for clinical decisions. Ann. Intern. Med. 1997, 126, 376-380. [CrossRef] [PubMed]

39. Webster, J.; Watson, R.T. Analyzing the Past to Prepare for the Future: Writing a Literature Review. MIS Q. 2002, 26, xiii-xxiii.

40. Timilsina, G.R.; Kurdgelashvili, L.; Narbel, P.A. Solar energy: Markets, economics and policies. Renew. Sustain. Energy Rev. 2012, 16, 449-465. [CrossRef]

41. Corbin, J.M.; Strauss, A. Grounded theory research: Procedures, canons, and evaluative criteria. Qual. Sociol. 1990, 13, 3-21. [CrossRef]

42. Yuan, H.; Shen, L. Trend of the research on construction and demolition waste management. Waste Manag. 2011, 31, 670-679. [CrossRef]

43. Zeng, K. Domestic Politics and US-China Trade Disputes over Renewable Energy. J. East Asian Stud. 2015, 15, 423-454. [CrossRef]

44. Cowern, N.E.B. Silicon-based photovoltaic solar cells. In Functional Materials for Sustainable Energy Applications; Woodhead Publishing: Cambridge, UK, 2012; pp. 3-22e.

45. Frenzel, M.; Tolosana-Delgado, R.; Gutzmer, J. Assessing the supply potential of high-tech metals-A general method. Resour. Policy 2015, 46, 45-58. [CrossRef]

46. Fthenakis, V.; Anctil, A. (Eds.) Direct Te mining: Resource availability and impact on cumulative energy demand of CdTe PV life cycles. In Proceedings of the 2012 IEEE 38th Photovoltaic Specialists Conference (PVSC) PART 2, Austin, TX, USA, 3-8 June 2012.

47. Hancock, L.; Ralph, N.; Armand, M.; Macfarlane, D.; Forsyth, M. In the lab: New ethical and supply chain protocols for battery and solar alternative energy laboratory research policy and practice. J. Clean. Prod. 2018, 187, 485-495. [CrossRef]

48. Kaja, H.; Barki, D.T. (Eds.) Solar PV technology value chain in respect of new silicon feedstock materials: A context of India and its ambitious National Solar Mission. In Proceedings of the 2011 Annual IEEE India Conference, Hyderabad, India, 16-18 December 2011.

49. Werner, T.T.; Mudd, G.M.; Jowitt, S.M. The world's by-product and critical metal resources part III: A global assessment of indium. Ore Geol. Rev. 2017, 86, 939-956. [CrossRef]

50. Woodhouse, M.; Goodrich, A.; Margolis, R.; James, T.L.; Lokanc, M.; Eggert, R. (Eds.) Supply-chain dynamics of tellurium, indium and gallium within the context of PV module manufacturing costs. In Proceedings of the 2012 IEEE 38th Photovoltaic Specialists Conference (PVSC) PART 2, Austin, TX, USA, 3-8 June 2012.

51. Di Sabatino, M.; Stokkan, G. Defect generation, advanced crystallization, and characterization methods for high-quality solar-cell silicon. Appl. Mater. Sci. 2013, 210, 641-648. [CrossRef]

52. Goodrich, A.; Hacke, P.; Wang, Q.; Sopori, B.; Margolis, R.; James, T.; Woodhouse, M. A wafer-based monocrystalline silicon photovoltaics road map: Utilizing known technology improvement opportunities for further reductions in manufacturing costs. Sol. Energy Mater. Sol. Cells 2013, 114, 110-135. [CrossRef]

53. Long, S.; Geng, S. Decision framework of photovoltaic module selection under interval-valued intuitionistic fuzzy environment. Energy Convers. Manag. 2015, 106, 1242-1250. [CrossRef]

54. Luo, W.; Khoo, Y.S.; Kumar, A.; Low, J.S.C.; Li, Y.M.; Tan, Y.S.; Ramakrishna, S. A comparative life-cycle assessment of photovoltaic electricity generation in Singapore by multicrystalline silicon technologies. Sol. Energy Mater. Sol. Cells 2018, 174, 157-162. [CrossRef]

55. Moser, D.; Del Buono, M.; Jahn, U.; Herz, M.; Richter, M.; De Brabandere, K. Identification of technical risks in the photovoltaic value chain and quantification of the economic impact. Prog. Photovolt. Res. Appl. 2017, 25, 592-604. [CrossRef]

56. Sheikh, N.J.; Park, Y.J.; Kocaoglu, D.F. (Eds.) Assessment of solar photovoltaic technologies using multiple perspectives and hierarchical decision modeling: Manufacturers worldview. In Proceedings of the PICMET'14 Conference: Portland International Center for Management of Engineering and Technology; Infrastructure and Service Integration, Kanazawa, Japan, 27-31 July 2014.

57. Steeman, R.; Yong, J.; Mjøs, Ø.; Song, A. Integrating the value chain: The impact of silicon quality on cell performance. Energy Procedia 2012, 15, 20-29. [CrossRef]

58. Dominguez Lacasa, I.; Shubbak, M.H. Drifting towards innovation: The co-evolution of patent networks, policy, and institutions in China's solar photovoltaics industry. Energy Res. Soc. Sci. 2018, 38, 87-101. [CrossRef]

59. Breukel, A.; Zeegers, H. Breakthrough innovations by locally embedded start-ups and SMEs in a global network. In Global Innovation and Entrepreneurship: Challenges and Experiences from East and West; Palgrave Macmillan: Cham, Switzerland, 2017; pp. 113-137. 
60. Chen, H.H.; Lee, A.H.I.; Chen, S. Strategic policy to select suitable intermediaries for innovation to promote PV solar energy industry in China. Appl. Energy 2014, 115, 429-437. [CrossRef]

61. Davies, J.; Joglekar, N. Supply Chain Integration, Product Modularity, and Market Valuation: Evidence from the Solar Energy Industry. Prod. Oper. Manag. 2013, 22, 1494-1508. [CrossRef]

62. Jayanthi, S.; Witt, E.C.; Singh, V. Evaluation of Potential of Innovations: A DEA-Based Application to U.S. Photovoltaic Industry. IEEE Trans. Eng. Manag. 2009, 56, 478-493. [CrossRef]

63. Wang, C.N.; Chang, Y.L.; Wu, T.C. A novel decision approach on selecting alliance partners of supply chain in photovoltaic industry. Afr. J. Bus. Manag. 2011, 5, 12702-12710.

64. Wang, R.; Mu, Y. (Eds.) The Impacts of Supply Chain Cooperation Activities on Firm's Market Value. In Proceedings of the 2019 16th International Conference on Service Systems and Service Management (ICSSSM), Shenzhen, China, 13-15 July 2019.

65. Aziz, S.; Chowdhury, S.A. (Eds.) A description of human resource development in the Solar Home System industry in Bangladesh. In Proceedings of the 2nd International Conference on the Developments in Renewable Energy Technology (ICDRET 2012), Dhaka, Bangladesh, 5-7 January 2012.

66. Llera, E.; Scarpellini, S.; Aranda, A.; Zabalza, I. Forecasting job creation from renewable energy deployment through a value-chain approach. Renew. Sustain. Energy Rev. 2013, 21, 262-271. [CrossRef]

67. Hanna, R.; Leach, M.; Torriti, J. Microgeneration: The installer perspective. Renew. Energy 2018, 116, 458-469. [CrossRef]

68. Shum, K.L.; Watanabe, C. Towards a local learning (innovation) model of solar photovoltaic deployment. Energy Policy 2008, 36, 508-521. [CrossRef]

69. Horváth, D.; Szabó, R.Z. Evolution of photovoltaic business models: Overcoming the main barriers of distributed energy deployment. Renew. Sustain. Energy Rev. 2018, 90, 623-635. [CrossRef]

70. Huijben, J.C.C.M.; Verbong, G.P.J. Breakthrough without subsidies? PV business model experiments in the Netherlands. Energy Policy 2013, 56, 362-370. [CrossRef]

71. Strupeit, L.; Palm, A. Overcoming barriers to renewable energy diffusion: Business models for customer-sited solar photovoltaics in Japan, Germany and the United States. J. Clean. Prod. 2016, 123, 124-136. [CrossRef]

72. Zhang, F.; Gallagher, K.S. Innovation and technology transfer through global value chains: Evidence from China's PV industry. Energy Policy 2016, 94, 191-203. [CrossRef]

73. Curtius, H.C. The adoption of building-integrated photovoltaics: Barriers and facilitators. Renew. Energy 2018, 126, 783-790. [CrossRef]

74. Davies, G. Clean energy product markets in sub-Saharan Africa: Complex market devices and power asymmetries. Energy Res. Soc. Sci. 2018, 42, 80-89. [CrossRef]

75. Grau, T.; Huo, M.; Neuhoff, K. Survey of photovoltaic industry and policy in Germany and China. Energy Policy 2012, 51, 20-37. [CrossRef]

76. Hanson, J. Established industries as foundations for emerging technological innovation systems: The case of solar photovoltaics in Norway. Environ. Innov. Soc. Transit. 2018, 26, 64-77. [CrossRef]

77. Hoffmann, W. PV solar electricity industry: Market growth and perspective. Sol. Energy Mater. Sol. Cells 2006, 90, 3285-3311. [CrossRef]

78. Hu, J.L.; Yeh, F.Y. The Value Migration and Innovative Capacity of Taiwan's Photovoltaic Industry. Energy Sources Part B Econ. Plan. Policy 2013, 8, 190-199. [CrossRef]

79. Huo, M.-L.; Zhang, D.-W. Lessons from photovoltaic policies in China for future development. Energy Policy 2012, 51, 38-45. [CrossRef]

80. Kebede, K.Y.; Mitsufuji, T. Diffusion of solar innovations in Ethiopia: Exploring systemic problems. Int. J. Technol. Manag. Sustain. Dev. 2014, 13, 53-72. [CrossRef]

81. Kemeny, P.; Munro, P.G.; Schiavone, N.; van der Horst, G.; Willans, S. Community Charging Stations in rural sub-Saharan Africa: Commercial success, positive externalities, and growing supply chains. Energy Sustain. Dev. 2014, 23, 228-236. [CrossRef]

82. Klitkou, A.; Coenen, L. The Emergence of the Norwegian Solar Photovoltaic Industry in a Regional Perspective. Eur. Plan. Stud. 2013, 21, 1796-1819. [CrossRef]

83. Lam, L.T.; Branstetter, L.; Azevedo, I.L. A sunny future: Expert elicitation of China's solar photovoltaic technologies. Environ. Res. Lett. 2018, 13, 034038. [CrossRef]

84. Li, H.L.; Chen, D.P.; Zhao, L.; Zhou, C.L.; Liu, Z.G.; Wang, W.J. PV demand and supply in China. Prog. Photovolt. Res. Appl. 2013, 21, 1286-1291. [CrossRef]

85. Newman, S.; Doig, S.; Hansen, L.; Lacy, V. (Eds.) Accelerating solar power adoption: Compounding cost savings across the value chain. In Proceedings of the 38th ASES National Solar Conference 2009, SOLAR 2009, Buffalo, NY, USA, 11-16 May 2009.

86. Nygaard, I.; Hansen, U.E.; Mackenzie, G.; Pedersen, M.B. Measures for diffusion of solar PV in selected African countries. Int. J. Sustain. Energy 2017, 36, 707-721. [CrossRef]

87. Pinkse, J.; van den Buuse, D. The development and commercialization of solar PV technology in the oil industry. Energy Policy 2012, 40, 11-20. [CrossRef]

88. Sekhar, K.; Mukundan, R.; Mohan, R.; Sharma, S.; Udayarajan, V.; Jain, K.; Momaya, K. (Eds.) Aligning technology licensing strategies and business competitiveness: A case of photovoltaic technology firms in India. In Proceedings of the 2011 Proceedings of PICMET '11: Technology Management in the Energy Smart World (PICMET), Portland, OR, USA, 31 July-4 August 2011. 
89. Su, Y.-S. Competing in the Global Solar Photovoltaic Industry: The case of Taiwan. Int. J. Photoenergy 2013, 2013, 11. [CrossRef]

90. Votteler, R.; Hough, J.; Venter, C. An analysis of the solar service provider industry in the Western Cape, South Africa. J. Energy S. Afr. 2014, 25, 70-80. [CrossRef]

91. Xiaohua, L. Institutional and economic support for renewable energy companies in China and EU member states: Conflicting or cooperative industrial policies? Perspect. Glob. Dev. Technol. 2014, 13, 728-754. [CrossRef]

92. Yu, Z. China's photovoltaic industry policy performance from the perspective of global value chain. Energy Sources Part A Recovery Util. Environ. Eff. 2018, 40, 1737-1742. [CrossRef]

93. Fang, H.; Wang, B.; Song, W. Analyzing the interrelationships among barriers to green procurement in photovoltaic industry: An integrated method. J. Clean. Prod. 2020, 249, 119408. [CrossRef]

94. Papageorgiou, K.; Carvalho, G.; Papageorgiou, E.I.; Bochtis, D.; Stamoulis, G. Decision-Making Process for Photovoltaic Solar Energy Sector Development using Fuzzy Cognitive Map Technique. Energies 2020, 13, 1427. [CrossRef]

95. Hipp, A.; Binz, C. Firm survival in complex value chains and global innovation systems: Evidence from solar photovoltaics. Res. Pol. 2020, 49, 103876. [CrossRef]

96. Matsuo, T. Fostering grid-connected solar energy in emerging markets: The role of learning spillovers. Energy Res. Soc. Sci. 2019, 57, 101227. [CrossRef]

97. Jin, J.; Zhang, Z.; Wang, L. From the Host to the Home Country, the International Upgradation of EMNEs in Sustainability Industries-The Case of a Chinese PV Company. Sustainability 2019, 11, 5269. [CrossRef]

98. Shum, R.Y. Heliopolitics: The international political economy of solar supply chains. Energy Strategy Rev. 2019, 26, 100390. [CrossRef]

99. Strielkowski, W.; Volkova, E.; Pushkareva, L.; Streimikiene, D. Innovative Policies for Energy Efficiency and the Use of Renewables in Households. Energies 2019, 12, 1392. [CrossRef]

100. Hughes, L.; Meckling, J. Policy competition in clean technology: Scaling up or innovating up? Bus. Politics 2018, 20, 588-614. [CrossRef]

101. Liu, Y.; Chen, J.; Wang, L. Research on Self-Organizing Evolution Level of China's Photovoltaic Industry Chain System. Sustainability 2020, 12, 1792. [CrossRef]

102. Shubbak, M.H. The technological system of production and innovation: The case of photovoltaic technology in China. Res. Pol. 2019, 48, 993-1015. [CrossRef]

103. Denes_Santos, D.; da Cunha, S.K. Transformative innovation policy for solar energy: Particularities of a developing country. Clean Technol. Environ. Policy 2020, 22, 43-57. [CrossRef]

104. Binz, C.; Anadon, L.D. Unrelated diversification in latecomer contexts: Emergence of the Chinese solar photovoltaics industry. Environ. Innov. Soc. Transit. 2018, 28, 14-34. [CrossRef]

105. Brock, A.; Sovacool, B.K.; Hook, A. Volatile Photovoltaics: Green Industrialization, Sacrifice Zones, and the Political Ecology of Solar Energy in Germany. Ann. Am. Assoc. Geogr. 2021,1-23. [CrossRef]

106. Hajdukiewicz, A.; Pera, B. International Trade Disputes over Renewable Energy-The Case of the Solar Photovoltaic Sector. Energies 2020, 13, 500. [CrossRef]

107. Cliburn, J.K.; Robertson, C. (Eds.) Integrated Utility-Driven Solar PV: Key to Keeping Clean Distributed Resources in the Race to Meet Carbon-Reduction Goals. In Proceedings of the 35th ASES National Solar Conference, Denver, CO, USA, 9-13 July 2006.

108. Corsatea, T.D.; Giaccaria, S.; Covrig, C.-F.; Zaccarelli, N.; Ardelean, M. RES diffusion and R\&D investments in the flexibilisation of the European electricity networks. Renew. Sustain. Energy Rev. 2016, 55, 1069-1082.

109. Fridgen, G.; Kahlen, M.; Ketter, W.; Rieger, A.; Thimmel, M. One rate does not fit all: An empirical analysis of electricity tariffs for residential microgrids. Appl. Energy 2018, 210, 800-814. [CrossRef]

110. Mills, A.D.; Wiser, R.H. (Eds.) An evaluation of solar valuation methods used in utility planning and procurement processes. In Proceedings of the 42nd ASES National Solar Conference 2013, SOLAR 2013, Baltimore, MD, USA, 16-20 April 2013.

111. Munson, K. Solar + storage: A holistic view. Renew. Energy Focus 2015, 16, 34-35. [CrossRef]

112. Tayal, D. Leveraging innovation for electricity utilities. Electr. J. 2017, 30, 23-29. [CrossRef]

113. Funcke, S. Municipal Added Value through Solar Power Systems in the City of Freiburg. Sustainability 2012, 4, 819. [CrossRef]

114. Martin, N.; Rice, J. Solar Feed-In Tariffs: Examining fair and reasonable retail rates using cost avoidance estimates. Energy Policy 2018, 112, 19-28. [CrossRef]

115. Migendt, M.; Polzin, F.; Schock, F.; Täube, F.A.; Flotow, P. Beyond venture capital: An exploratory study of the finance-innovationpolicy nexus in cleantech. Ind. Corp. Chang. 2017, 26, 973-996. [CrossRef]

116. Shum, K.L.; Watanabe, C. Photovoltaic deployment strategy in Japan and the USA-An institutional appraisal. Energy Policy 2007, 35, 1186-1195. [CrossRef]

117. Dehghani Madvar, M.; Alhuyi Nazari, M.; Tabe Arjmand, J.; Aslani, A.; Ghasempour, R.; Ahmadi, M.H. Analysis of stakeholder roles and the challenges of solar energy utilization in Iran. Int. J. Low-Carbon Technol. 2018, 13, 438-451. [CrossRef]

118. Chen, Z.; Ivan Su, S.-I. Social welfare maximization with the least subsidy: Photovoltaic supply chain equilibrium and coordination with fairness concern. Renew. Energy 2019, 132, 1332-1347. [CrossRef]

119. Xu, Y.; Li, J.; Tan, Q.; Peters, A.L.; Yang, C. Global status of recycling waste solar panels: A review. Waste Manag. 2018, 75, 450-458. [CrossRef] 
120. D'Adamo, I.; Miliacca, M.; Rosa, P. Economic Feasibility for Recycling of Waste Crystalline Silicon Photovoltaic Modules. Int. J. Photoenergy 2017, 2017, 6. [CrossRef]

121. Corcelli, F.; Ripa, M.; Leccisi, E.; Cigolotti, V.; Fiandra, V.; Graditi, G.; Sannino, L.; Tammaro, M.; Ulgiati, S. Sustainable urban electricity supply chain-Indicators of material recovery and energy savings from crystalline silicon photovoltaic panels end-of-life. Ecol. Indic. 2018, 94, 37-51. [CrossRef]

122. Hsueh, J.-T.; Lin, C.-Y. Constructing a network model to rank the optimal strategy for implementing the sorting process in reverse logistics: Case study of photovoltaic industry. Clean Technol. Environ. Policy 2015, 17, 155-174. [CrossRef]

123. Kim, S.; Jeong, B. Closed-Loop Supply Chain Planning Model for a Photovoltaic System Manufacturer with Internal and External Recycling. Sustainability 2016, 8, 596. [CrossRef]

124. Shiue, Y.C.; Lin, C.Y. Applying analytic network process to evaluate the optimal recycling strategy in upstream of solar energy industry. Energy Build. 2012, 54, 266-277. [CrossRef]

125. Kharaji Manouchehrabadi, M.; Yaghoubi, S. A game theoretic incentive model for closed-loop solar cell supply chain by considering government role. Energy Sources Part A Recovery Util. Environ. Eff. 2020, 1-25. [CrossRef]

126. Wu, J.; Zhang, Q.; Xu, Z. Research on China's photovoltaic modules recycling models under extended producer responsibility. Int. J. Sustain. Eng. 2019, 12, 423-432. [CrossRef]

127. Li, Q.; Liu, K.; Zhang, Z.-H. Robust design of a strategic network planning for photovoltaic module recycling considering reclaimed resource price uncertainty. IISE Trans. 2019, 51, 691-708. [CrossRef]

128. Quansah, D.A.; Adaramola, M.S. Ageing and degradation in solar photovoltaic modules installed in northern Ghana. Sol. Energy 2018, 173, 834-847. [CrossRef]

129. Guo, X.; Lin, K.; Huang, H.; Li, Y. Carbon footprint of the photovoltaic power supply chain in China. J. Clean. Prod. 2019, 233, 626-633. [CrossRef]

130. Jäger-Waldau, A.; Kougias, I.; Taylor, N.; Thiel, C. How photovoltaics can contribute to GHG emission reductions of $55 \%$ in the EU by 2030. Renew. Sustain. Energy Rev. 2020, 126, 109836. [CrossRef]

131. Agnew, S.; Smith, C.; Dargusch, P. Causal loop modelling of residential solar and battery adoption dynamics: A case study of Queensland, Australia. J. Clean. Prod. 2018, 172, 2363-2373. [CrossRef]

132. Bulman, P. Tesla's Powerwall battery production requires 'super-charged' supply chain. Renew. Energy Focus 2015, 16, 126-127. [CrossRef]

133. Canals Casals, L.; Amante García, B.; Cremades, L.V. Electric vehicle battery reuse: Preparing for a second life. J. Ind. Eng. Manag. 2017, 10, 266-285. [CrossRef]

134. Gaines, L. Lithium-ion battery recycling processes: Research towards a sustainable course. Sustain. Mater. Technol. 2018, 17, e00068. [CrossRef]

135. Golembiewski, B.; vom Stein, N.; Sick, N.; Wiemhöfer, H.-D. Identifying trends in battery technologies with regard to electric mobility: Evidence from patenting activities along and across the battery value chain. J. Clean. Prod. 2015, 87, 800-810. [CrossRef]

136. Huang, B.; Pan, Z.; Su, X.; An, L. Recycling of lithium-ion batteries: Recent advances and perspectives. J. Power Sources 2018, 399, 274-286. [CrossRef]

137. Jiao, N.; Evans, S. Business Models for Sustainability: The Case of Second-life Electric Vehicle Batteries. In Proceedings of the 13th Global Conference on Sustainable Manufacturing, Binh Duong, Vietnam, 16-18 September 2015; pp. $250-255$.

138. Martinez-Laserna, E.; Gandiaga, I.; Sarasketa-Zabala, E.; Badeda, J.; Stroe, D.I.; Swierczynski, M.; Goikoetxea, A. Battery second life: Hype, hope or reality? A critical review of the state of the art. Renew. Sustain. Energy Rev. 2018, 93, 701-718. [CrossRef]

139. Neubauer, J.; Wood, E.; Pesaran, A. A Second Life for Electric Vehicle Batteries: Answering Questions on Battery Degradation and Value. SAE Int. J. Mater. Manuf. 2015, 8, 544-553. [CrossRef]

140. Olsson, L.; Fallahi, S.; Schnurr, M.; Diener, D.; van Loon, P. Circular Business Models for Extended EV Battery Life. Batteries 2018, 4, 57. [CrossRef]

141. Ordoñez, J.; Gago, E.J.; Girard, A. Processes and technologies for the recycling and recovery of spent lithium-ion batteries. Renew. Sustain. Energy Rev. 2016, 60, 195-205. [CrossRef]

142. Ramoni, M.O.; Zhang, H.-C. End-of-life (EOL) issues and options for electric vehicle batteries. Clean Technol. Environ. Policy 2013, 15, 881-891. [CrossRef]

143. Schneider, M.; Biel, K.; Pfaller, S.; Schaede, H.; Rinderknecht, S.; Glock, C.H. Using inventory models for sizing energy storage systems: An interdisciplinary approach. J. Energy Storage 2016, 8, 339-348. [CrossRef]

144. Sick, N.; Bröring, S.; Figgemeier, E. Start-ups as technology life cycle indicator for the early stage of application: An analysis of the battery value chain. J. Clean. Prod. 2018, 201, 325-333. [CrossRef]

145. Stenzel, P.; Baumann, M.; Fleer, J.; Zimmermann, B.; Weil, M. (Eds.) Database development and evaluation for techno-economic assessments of electrochemical energy storage systems. In Proceedings of the Energycon 2014-IEEE International Energy Conference, Cavtat, Croatia, 13-16 May 2014.

146. Sun, S.I.; Chipperfield, A.J.; Kiaee, M.; Wills, R.G.A. Effects of market dynamics on the time-evolving price of second-life electric vehicle batteries. J. Energy Storage 2018, 19, 41-51. [CrossRef]

147. Zheng, X.; Zhu, Z.; Lin, X.; Zhang, Y.; He, Y.; Cao, H.; Sun, Z. A Mini-Review on Metal Recycling from Spent Lithium Ion Batteries. Engineering 2018, 4, 361-370. [CrossRef] 
148. Retna Kumar, A.; Shrimali, G. Battery storage manufacturing in India: A strategic perspective. J. Energy Storage $2020,32,101817$. [CrossRef]

149. Chen, M.; Ma, X.; Chen, B.; Arsenault, R.; Karlson, P.; Simon, N.; Wang, Y. Recycling End-of-Life Electric Vehicle Lithium-Ion Batteries. Joule 2019, 3, 2622-2646. [CrossRef]

150. Liu, J.; Li, Y.; Lu, Y.; Yan, S. Study on coupling optimization model of node enterprises for energy storage-involved photovoltaic value chain in China. Energy Rep. 2020, 6, 69-81. [CrossRef]

151. Agnew, S.; Smith, C.; Dargusch, P. Understanding transformational complexity in centralized electricity supply systems: Modelling residential solar and battery adoption dynamics. Renew. Sustain. Energy Rev. 2019, 116, 109437. [CrossRef]

152. Abdallah, T.; Diabat, A.; Rigter, J. Investigating the option of installing small scale PVs on facility rooftops in a green supply chain. Int. J. Product. Econ. 2013, 146, 465-477. [CrossRef]

153. Basore, P.A.; Cole, W.J. Comparing supply and demand models for future photovoltaic power generation in the USA. Prog. Photovolt. Res. Appl. 2018, 26, 414-418. [CrossRef]

154. Castellanos, S.; Santibañez-Aguilar, J.E.; Shapiro, B.B.; Powell, D.M.; Peters, I.M.; Buonassisi, T.; Kammen, D.M.; FloresTlacuahuac, A. Sustainable silicon photovoltaics manufacturing in a global market: A techno-economic, tariff and transportation framework. Appl. Energy 2018, 212, 704-719. [CrossRef]

155. Chen, Z.; Su, S.-I.I. Photovoltaic supply chain coordination with strategic consumers in China. Renew. Energy 2014, 68, 236-244. [CrossRef]

156. Chen, Z.; Su, S.-I.I. Dual Competing Photovoltaic Supply Chains: A Social Welfare Maximization Perspective. Int. J. Environ. Res. Public Health 2017, 14, 1416. [CrossRef]

157. Chen, Z.; Su, S.-I.I. Multiple competing photovoltaic supply chains: Modeling, analyses and policies. J. Clean. Prod. 2018, 174, 1274-1287. [CrossRef]

158. Chiaroni, D.; Chiesa, V.; Colasanti, L.; Cucchiella, F.; D'Adamo, I.; Frattini, F. Evaluating solar energy profitability: A focus on the role of self-consumption. Energy Convers. Manag. 2014, 88, 317-331. [CrossRef]

159. Cucchiella, F.; D’Adamo, I.; Gastaldi, M.; Koh, S.C.L. Renewable energy options for buildings: Performance evaluations of integrated photovoltaic systems. Energy Build. 2012, 55, 208-217. [CrossRef]

160. Cucchiella, F.; D'Adamo, I.; Lenny Koh, S.C. Environmental and economic analysis of building integrated photovoltaic systems in Italian regions. J. Clean. Prod. 2015, 98, 241-252. [CrossRef]

161. Dehghani, E.; Jabalameli, M.S.; Jabbarzadeh, A.; Pishvaee, M.S. Resilient solar photovoltaic supply chain network design under business-as-usual and hazard uncertainties. Comput. Chem. Eng. 2018, 111, 288-310. [CrossRef]

162. Goodrich, A.; Powell, D.; James, T.; Woodhouse, M.; Buonassisi, T. Assessing the drivers of regional trends in solar photovoltaic manufacturing. Energy Environ. Sci. 2013, 6, 2811-2821. [CrossRef]

163. Koppelaar, R.H.E.M. Solar-PV energy payback and net energy: Meta-assessment of study quality, reproducibility, and results harmonization. Renew. Sustain. Energy Rev. 2017, 72, 1241-1255. [CrossRef]

164. Lee, S.-Y.; Klassen, R.D. Drivers and Enablers That Foster Environmental Management Capabilities in Small- and Medium-Sized Suppliers in Supply Chains. Prod. Oper. Manag. 2008, 17, 573-586. [CrossRef]

165. Liu, J.; Xu, F.; Lin, S. Site selection of photovoltaic power plants in a value chain based on grey cumulative prospect theory for sustainability: A case study in Northwest China. J. Clean. Prod. 2017, 148, 386-397. [CrossRef]

166. Loomis, D.G.; Jo, J.H.; Aldeman, M.R. Economic impact potential of solar photovoltaics in Illinois. Renew. Energy 2016, 87, 253-258. [CrossRef]

167. Meckling, J.; Hughes, L. Globalizing Solar: Global Supply Chains and Trade Preferences. Int. Stud. Q. 2017, 61, 225-235. [CrossRef]

168. Sawhney, R.; Thakur, K.; Venkatesan, B.; Ji, S.; Upreti, G.; Sanseverino, J. Empirical analysis of the solar incentive policy for Tennessee solar value chain. Appl. Energy 2014, 131, 368-376. [CrossRef]

169. Tanaka, K.; Inoue, T.; Matsuhashi, R.; Yamada, K. Global value chain assessment based on retrospectively induced economic costs associated with technology application: A case study of photovoltaic power system in Japan. J. Clean. Prod. 2018, 181, 460-472. [CrossRef]

170. Yang, R.J.; Zou, P.X.W. Building integrated photovoltaics (BIPV): Costs, benefits, risks, barriers and improvement strategy. Int. J. Constr. Manag. 2016, 16, 39-53. [CrossRef]

171. Zanoni, S.; Mazzoldi, L. Long term analysis of energy payback time for pv systems. In Proceedings of the IFIP WG 5.7 International Conference, APMS 2013, State College, PA, USA, 9-12 September 2013; pp. 395-401.

172. Zhang, Y.H.; Wang, Y. The impact of government incentive on the two competing supply chains under the perspective of Corporation Social Responsibility: A case study of Photovoltaic industry. J. Clean. Prod. 2017, 154, 102-113. [CrossRef]

173. Hoang, P.; Goffe, B.; Jacquemin, L.; Billaudot, H.A.; Archambault, V. What metrics to evaluate sustainability of photovoltaic systems? Metall. Res. Technol. 2014, 111, 201-210. [CrossRef]

174. Dehghani, E.; Jabalameli, M.S.; Naderi, M.J.; Safari, A. An environmentally conscious photovoltaic supply chain network design under correlated uncertainty: A case study in Iran. J. Clean. Prod. 2020, 262, 121434. [CrossRef]

175. Albrecht, W.; Steinrücke, M. Continuous-time scheduling of production, distribution and sales in photovoltaic supply chains with declining prices. Flex. Serv. Manuf. J. 2020, 32, 629-667. [CrossRef] 
176. Santibañez-Aguilar, J.E.; Castellanos, S.; Flores-Tlacuahuac, A.; Shapiro, B.B.; Powell, D.M.; Buonassisi, T.; Kammen, D.M. Design of domestic photovoltaics manufacturing systems under global constraints and uncertainty. Renew. Energy 2020, 148, 1174-1189. [CrossRef]

177. Liu, J.; Lin, X. Empirical analysis and strategy suggestions on the value-added capacity of photovoltaic industry value chain in China. Energy 2019, 180, 356-366. [CrossRef]

178. Chen, Z.; Su, S.-I.I. International competition and trade conflict in a dual photovoltaic supply chain system. Renew. Energy 2020, 151, 816-828. [CrossRef]

179. Kharaji Manouchehrabadi, M.; Yaghoubi, S.; Tajik, J. Optimal scenarios for solar cell supply chain considering degradation in powerhouses. Renew. Energy 2020, 145, 1104-1125. [CrossRef]

180. Kharaji Manouchehrabadi, M.; Yaghoubi, S. Solar cell supply chain coordination and competition under government intervention. J. Renew. Sustain. Energy 2019, 11, 023701. [CrossRef]

181. Yadav, S.; Chattopadhyay, K.; Singh, C.V. Solar grade silicon production: A review of kinetic, thermodynamic and fluid dynamics based continuum scale modeling. Renew. Sustain. Energy Rev. 2017, 78, 1288-1314. [CrossRef]

182. Boons, F.; Lüdeke-Freund, F. Business models for sustainable innovation: State-of-the-art and steps towards a research agenda. J. Clean. Prod. 2013, 45, 9-19. [CrossRef] 